\title{
Observations of sand waves, megaripples, and hummocks in the Dutch coastal area and their relation to currents and combined flow conditions
}

\author{
S. Passchier ${ }^{1}$ \\ TNO-Built Environment and Geosciences, Geology Division, National Geological Survey, \\ Utrecht, Netherlands \\ M. G. Kleinhans \\ Faculty of Geosciences, Institute for Marine and Atmospheric Research Utrecht, Utrecht, Netherlands
}

Received 30 July 2004; revised 9 September 2005; accepted 10 October 2005; published 17 December 2005.

[1] This paper aims to investigate the distribution and stability of large-scale bed forms in response to storm and fair-weather conditions in a shallow marine environment. Multibeam and side-scan sonar data off the Dutch coast (median grain size $0.25-$ $0.35 \mathrm{~mm})$ were collected to monitor sand waves $(\lambda=100-800 \mathrm{~m})$ and superimposed megaripples $(\lambda=1-40 \mathrm{~m})$ through multiple storm and fair-weather events. Box cores were used to observe the vertical bed structure and grain size. In the Dutch coastal area, two-dimensional (2-D) megaripples $(\lambda=1-15 \mathrm{~m})$ are the dominant bed forms in current-dominated $(>0.4 \mathrm{~m} / \mathrm{s})$ tidal flow regimes with oscillatory flows $<0.15 \mathrm{~m} / \mathrm{s}$. Effects of trapping of fine material under these conditions by tube building Lanice conchilega colonies on bed form development are suspected but need further study. At slightly higher energy conditions, 3-D megaripples $(\lambda=5-15 \mathrm{~m})$ begin to form on the shoreface. After seasonal storms, at oscillatory flows $>0.4 \mathrm{~m} / \mathrm{s}$, undulating bed topography of mound-like 3-D bed forms $(\lambda=20-40 \mathrm{~m})$ is observed. Immediately after storms, these bed forms are covered by smaller 3-D megaripples, which are related to sets of low-angle converging laminae in box cores, interpreted as hummocky cross stratification (HCS). The sand waves form compound bed forms of sets of 2-D and 3-D megaripples. The morphology of the sand waves is a function of the general wind-wave climate of the marine environmental setting, with flat-topped 3-D sand waves occurring in shallow wave-dominated settings and 2-D sand waves occurring in the tide-dominated environment farther offshore.

Citation: Passchier, S., and M. G. Kleinhans (2005), Observations of sand waves, megaripples, and hummocks in the Dutch coastal area and their relation to currents and combined flow conditions, J. Geophys. Res., 110, F04S15, doi:10.1029/2004JF000215.

\section{Introduction}

[2] This paper discusses the stability of large-scale bed forms through periods of fair-weather conditions and multiple seasonal storm events. The purpose of this study is twofold. First, sustainable development of densely populated coastal areas requires knowledge of the morphodynamics of the seabed in e.g., navigation, the construction of pipelines and cables on the seafloor, or ecological marine habitat studies. Second, relating bed forms to flow conditions provides geologists with a modern reference to interpret ancient deposits.

[3] Process studies in flow ducts and in the field concentrate on small-scale bed forms $(<5 \mathrm{~m})$ due to the

\footnotetext{
${ }^{1}$ Now at Department of Earth and Environmental Studies, Montclair State University, Montclair, New Jersey, USA.

Copyright 2005 by the American Geophysical Union. 0148-0227/05/2004JF000215
}

size limitations of the measuring setup [e.g., Arnott and Southard, 1990; Li and Amos, 1999a, 1999b]. However, larger compound bed forms ( $>15 \mathrm{~m}$ wavelength), consisting internally of smaller bed forms have been observed in outcrop studies [e.g., Mitgaard, 1996]. The presence of ripples, megaripples and sand waves as superimposed bed forms in shallow shelf seas was observed previously [e.g., Terwindt, 1971; Field et al., 1981], but their mutual relations remain poorly understood. At present data from modern environments on the formation and dynamics of bed forms of $>5 \mathrm{~m}$ wavelength in response to changing hydrodynamic conditions is largely lacking. Therefore a periodic monitoring study was carried out as a complimentary approach to process studies to provide data on the behavior of bed forms at larger temporal and spatial scales.

[4] Megaripples of variable 2-D and 3-D morphologies are characteristic of modern nearshore environments, including the shoreface, and the surf zone [e.g., Field et al., 1981; Swift et al., 1983; Van de Meene et al., 1996; 
Gallagher, 2003]. Megaripples are defined here as a class of subaquatic dunes [Ashley et al., 1990] with wavelengths $1-$ $40 \mathrm{~m}$ and amplitudes up to $1.5 \mathrm{~m}$. In the North Sea, they are found on portions of flat seabed or occur superimposed on larger dunes of generally $100-800 \mathrm{~m}$ wavelength with amplitudes up to $17 \mathrm{~m}$, here referred to as sand waves [Terwindt, 1971; Passchier, 2004]. Bed forms occur as twodimensional (2-D) and three-dimensional forms (3-D). The geometry of 2-D bed forms is adequately described by one transect parallel to flow, whereas 3-D bed forms require multiple transects. A common type of 3-D megaripples found in nearshore deposits is characterized as low-angle bedding with converging laminae, interpreted as reflecting the length and migration of hummocks, up to several meters long and a few decimeters high [e.g., Greenwood and Sherman, 1986; Van de Meene et al., 1996; Hill et al., 2003].

\subsection{Megaripples and Hummocks}

[5] At shallow water depths and during storm events wave action is an important factor in bed form development. Increasing wind and waves cause complex combined flow conditions under accelerating and decelerating oscillatory and unidirectional current velocities. Process studies show that during storm events, bed configurations generally change from small bed forms to large bed forms, and to plane bed and back, leaving a complex seabed morphology of superimposed bed forms [e.g., Swift et al., 1983; Arnott and Southard, 1990; Myrow and Southard, 1991; Van de Meene et al., 1996; Li and Amos, 1999a]. Greenwood and Sherman [1986] observed the development of hummocks in a storm-dominated surf zone and attribute them to a dominant wave induced flow regime. Southard et al. [1990] found that hummocks scale to some extent with orbital diameter under purely oscillatory flow, and $L i$ and Amos [1999b] conclude that large wave ripples observed immediately after the peak of a storm with sheet flow conditions are actually hummocks. In contrast, Gallagher [2003] proposes that megaripples in the surf zone are steady flow dunes with complex geometries due to modifications by combined flow processes, including oscillatory flows. Hill et al. [2003] attribute hummocky cross stratification on the shoreface of a wave-dominated delta to the development of large weakly asymmetrical 3-D ripples under combined flows with weak unidirectional current velocities during the waning phases of storms. Others favor involvement of stronger unidirectional geostrophic or tidal currents superimposed on oscillatory currents in the formation of hummocky cross stratification [e.g., Swift et al., 1983; Mitgaard, 1996; Van de Meene et al., 1996].

[6] The relative influence of current and wave regimes on the formation of hummocks and megaripples remains a major issue and the question is whether hummocks and megaripples are a continuum of related bed forms, or that they have narrowly defined stability fields of specific flow conditions.

\subsection{Sand Waves and Megaripples}

[7] Field et al. [1981] observed a hierarchy of bed forms on an epicontinental shelf with three sizes of superimposed bed forms: sand waves with megaripples lying at a small oblique angle on their stoss slopes, with in turn linguoid or straight-crested ripples on the stoss slopes of the megaripples. Sand waves with superimposed megaripples are common observations in acoustic surveys of continental shelves, including the North Sea [Terwindt, 1971]; ripples are usually too small to be observed on multibeam and sidescan sonar records. In the North Sea, two types of megaripples are observed: straight 2-D megaripples are the common types, and rarely sand wave crests with 3-D megaripples are encountered [Passchier, 2004]. Field data collected in similar environmental settings shows that the morphology of sand wave crests changes in response to tidal and wave conditions [Langhorne, 1982; Field et al., 1981]. In contrast, megaripples are more dynamic features [Field et al., 1981]. Migration of megaripples of dm/day is common in tidal and subtidal environments [Wever, 2004].

[8] Morphodynamic modeling studies using linear stability analysis have been used successfully to predict the distribution of sand waves as a response to tidal flow in the Southern Bight of the North Sea [Hulscher and Van den Brink, 2001]. The models show that sand waves can be regarded as flow transverse bed forms with crest orientations deviating up to $10^{\circ}$ clockwise from the direction perpendicular to the principle current [Hulscher, 1996], which is similar to angles of $10-15^{\circ}$ measured in the southern North Sea [Hennings et al., 2000]. Further analyses with application of a superimposed steady current propose that tidal currents are the main control in sand wave generation, whereas a steady current causes sand wave migration of $5-10 \mathrm{~m} / \mathrm{yr}$ [Németh et al., 2002]. A similar modeling study that included the generation of megaripples indicated that the growth rates for the megaripples were several orders of magnitude higher than those for the sand waves [Idier and Astruc, 2004]. In the model the mechanisms of megaripple generation depended on water depth, surface waves, and the presence of preexisting ripples, megaripples or sand waves. The model did not yield an obvious relation between sand wave and megaripple generation.

[9] Here we are studying the behavior of sand waves, megaripples and hummocks in response to fair-weather periods and storm events in the Dutch coastal area through the analyses of sonar imagery, wind, wave and current records, and bedding features in box cores. During 2001, bed form types and distribution were monitored in three research areas in the Dutch coastal zone within the framework of the Delft Cluster project "Ecomorphodynamics of the Seafloor." In 2002 and 2003 one of the areas on the shoreface was revisited within the framework of the European SANDPIT project.

\section{Studied Area}

[10] Offshore, the Dutch continental shelf is covered with superimposed tidal sand ridges, sand waves and megaripples. The shoreface is morphologically diverse and along the central part it is characterized by a ridge-and-swale topography. The orientations of crest lines of the ridges are offset clockwise with respect to the coast-parallel tidal current (Figure 1). The attachment point of these shoreface-connected ridges lies on the lower shoreface at water depths between 14 and $15 \mathrm{~m}$ [Van Alphen and Damoiseaux, 1989]. The tidal amplitude in the area is $1.5 \mathrm{~m}$ to $2 \mathrm{~m}$. 

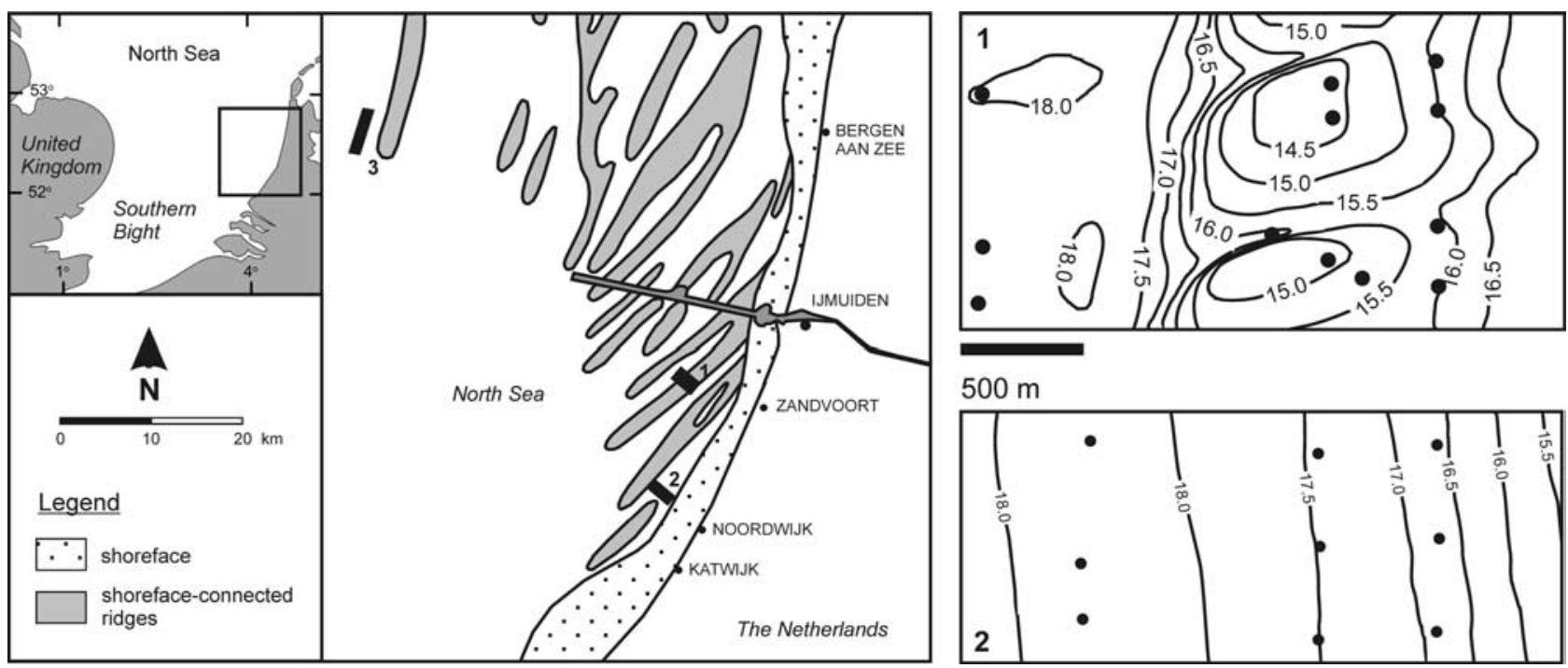

Figure 1. (left) Location of study areas in the Netherlands coastal zone and (right) detailed bathymetry of the study areas on the lower shoreface. Dots (Figure 1, right) are sample locations. Morphology (Figure 1, left) is after Van Alphen and Damoiseaux [1989]. Area 3 is situated in water depths of 25$30 \mathrm{~m}$.

Current velocities at $1 \mathrm{~m}$ above the bed are typically $0.2-$ $0.5 \mathrm{~m} / \mathrm{s}$ during fair-weather conditions [Van de Meene and van Rijn, 2000]. Characteristic observed storm conditions produce significant wave heights of $3-4 \mathrm{~m}$ and currents of $0.6 \mathrm{~m} / \mathrm{s}$ [Van de Meene, 1994]. Two research areas $(1 \mathrm{~km} \times$ $2.5 \mathrm{~km}$ ) are situated within the shoreface-connected ridge complex and comprise lower shoreface to inner shelf transitions, and one research area $(1 \mathrm{~km} \times 5 \mathrm{~km})$ is situated offshore on the shelf. Area 1 is part of a shorefaceconnected ridge and swale, approx. $10 \mathrm{~km}$ West of Zandvoort with water depths $15-18 \mathrm{~m}$. Area 2 is a sloping surface landward of some shore-oblique ridges, approx. $5 \mathrm{~km}$ west of Noordwijk with water depths $14-18 \mathrm{~m}$. This research area has a concave profile with a steep upper part (1:400) and a swale. Seaward of the swale are two very low shore-oblique ridges, which fall outside the survey area. Area 3 is located $55 \mathrm{~km}$ west of Bergen aan Zee in water depths of $25-30 \mathrm{~m}$. It is characterized by $1-3 \mathrm{~m}$ high sand waves with a wavelength of $\sim 200 \mathrm{~m}$ (Figure 2). The mean annual wave height measured at Meetpost Noordwijk (MPN, water depth $18 \mathrm{~m}$ ), near area 2, was $1.0 \mathrm{~m}$ in 2001 with wave heights larger than $3.5 \mathrm{~m}<1 \%$ of the time during seasonal storms. Significant wave heights for peak storm conditions were $0.5-1 \mathrm{~m}$ higher at station IJmuiden Munitiestortplaats (YM6, water depth $21 \mathrm{~m}$ ), near areas 1 and 3, but similar under low-energy conditions. The dominant wind direction is from the SW, but the largest waves are generated by NW storms, which have low frequency.

[11] Within the framework of the EU project SANDPIT two research sites were studied near area 2: the first site
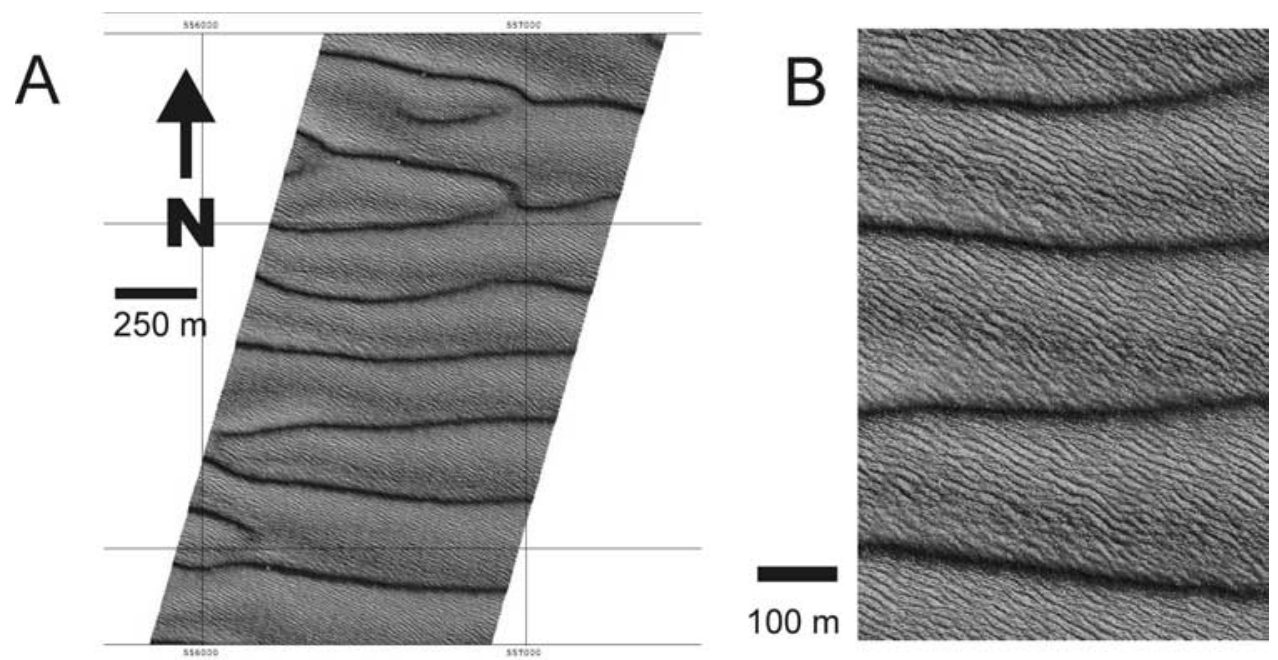

Figure 2. Shaded relief image of a part of area 3 with (a) sand waves and superimposed megaripples and (b) a detail from the center of Figure 2a. Water depths are $25 \mathrm{~m}$ at sand wave crests and $30 \mathrm{~m}$ in sand wave troughs. 

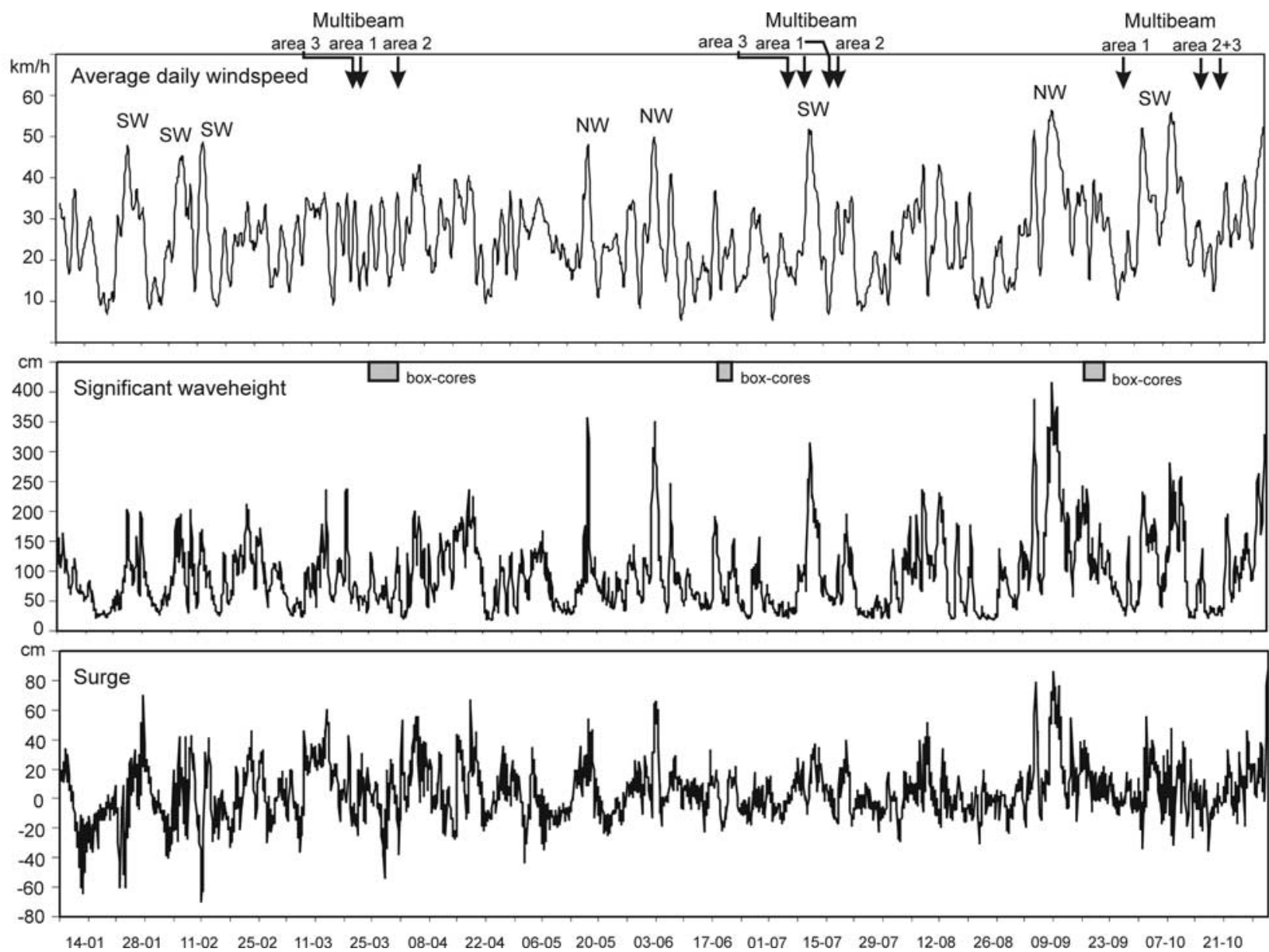

Figure 3. Average daily wind speed and significant wave height and surge height as 3-hour averages measured at Meetpost Noordwijk $(\mathrm{h}=18 \mathrm{~m}$ ) for the period 7 January until 31 October 2001 (source is Golfklimaat, http://www.golfklimaat.nl). In Figure 3 (top), wind direction is indicated by southwest (SW) and northwest $(\mathrm{NW})$.

(NW2) is $2 \mathrm{~km}$ offshore on the shoreface and the second (NW8.5) $8.5 \mathrm{~km}$ offshore (water depths 12 and $18 \mathrm{~m}$, respectively). The SANDPIT sites were part of a crossshore transect extending between 2 and $20 \mathrm{~km}$ off the coast.

\section{Methods}

[12] Data acquisition occurred during fair-weather conditions. In 2001 no major storms were observed and the monitoring can be considered as a fair-weather survey with seasonal storms of moderate intensity (Figure 3). Swath bathymetry was recorded using a Kongsberg Simrad EM 3000 D system, installed aboard the M.S. Arca of the State Department of Public Works. This hull-mounted system operates at a central frequency of $300 \mathrm{kHz}$ and uses 254 beams. The multibeam data were obtained using $20 \mathrm{~m}$ track line spacing creating a minimal overlap. The SANDPIT sites were mapped with multibeam and sonarimaging techniques in October 2002 (sonar only) after a large storm $\left(\mathrm{H}_{\mathrm{sig}}<6 \mathrm{~m}\right)$ and in February 2003 (sonar and multibeam) during fair weather conditions. Tide and velocity correction was accomplished using data collected on board and data from the Eveline Buoy (area 3), the MO12 buoy near area 1, and the tide stations at Meetpost
Noordwijk (MPN), and IJmuiden Munitiestortplaats (YM6). Relief maps were produced with oblique illumination and detailed bathymetric profiles were generated along transects across the research areas.

[13] Bed form characteristics and dimensions were determined from the relief maps and the profiles by manual measurements. Ranges of amplitudes were determined from the profiles by determining the difference between two lines, one through the troughs and one through the crests of the bed forms. The standard error in the bathymetry related to the conversion of the acoustic signal to water depth and the application of a tidal model is in the order of $0.15 \mathrm{~m}$, which is important when comparing data from different surveys. However, local changes in the bed morphology measured during one survey (with the same standard error), and thus bed form amplitudes, are precise on a centimeter-scale resolution. The positioning error is up to a few meters and the horizontal resolution of the multibeam data is $1 \times 1 \mathrm{~m}$, which is sufficient to observe bed forms of megaripple scale (meter-scale wavelength), but insufficient to resolve ripples (centimeter-scale wavelengths). Ranges of average wavelengths of 2-D bed forms were determined by repetitive counts of $\sim 10$ bed forms along the known length of a transect at right angles to the crest orientations of the 


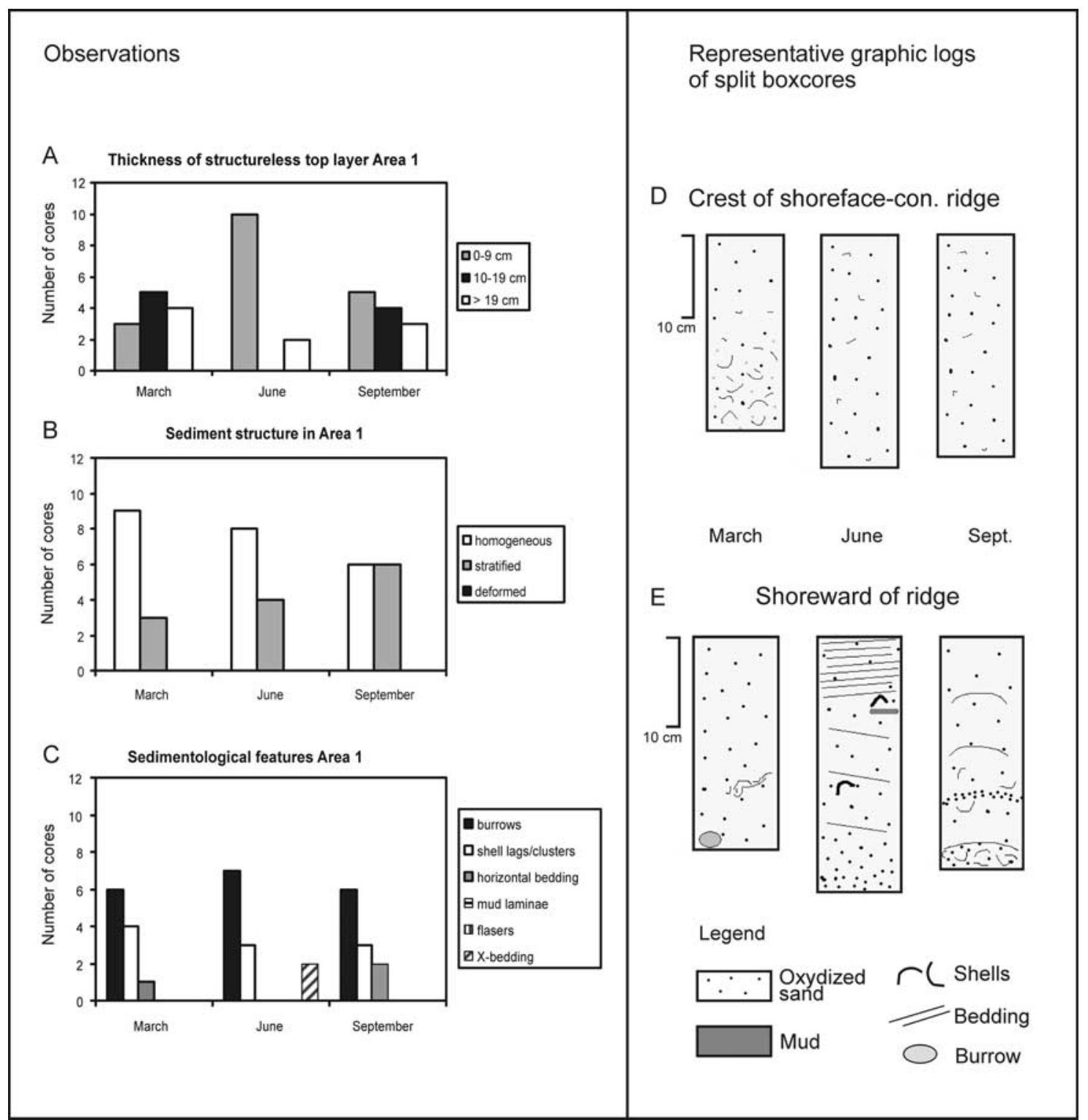

Figure 4. Sedimentology observed in $10 \mathrm{~cm}$ diameter split cores taken from box cores on the shorefaceconnected ridge (area 1). (a) Thickness of structureless top layer. (b) Sediment structure. Homogeneous is uniform lithological/sedimentological properties; stratified is more units with different lithological/ sedimentological properties; deformed is one or more units with deformed bedding or deformed lithological contacts. (c) Sedimentological features recorded on the cut face of the cores. (d) Graphic logs for three samples from the same station on the crest of the shoreface-connected ridge. (e) Graphic logs for three samples from the same station shoreward of the shoreface-connected ridge.

bed forms. For 3-D bed forms repetitive counts were made along several transects with different orientations.

[14] In 2001, bottom samples were obtained using a cylinder-shaped box corer with a diameter of $32 \mathrm{~cm}$. The March and June corings can be considered a fair-weather situation, whereas the September campaign occurred after a seasonal storm (Figure 3). Penetration varied between 0.2 and $0.3 \mathrm{~m}$. Lithology, structure and sedimentological features of the seabed were monitored in $10 \mathrm{~cm}$ diameter core samples covering 12 sampling stations in area 1, 9 stations in area 2, and 11-16 stations in area 3. Grain size distributions $(<2 \mathrm{~mm})$ of the top lithological units were analyzed using untreated samples in a Malvern Mastersizer 2000 laser particle sizer. Median grain size $\left(\mathrm{D}_{50}\right)$ and uniformity coefficient $\left(\mathrm{D}_{60} / \mathrm{D}_{10}\right.$ [U.S. Army Corps of Engineers, 1953]) were calculated. These measures are particularly useful when determining differences in size and sorting of coarse-grained sediments. Reineck box cores were collected from the SANDPIT sites in November 2002 (poststorm) and in September 2003 (fair-weather situation). Lacquer profiles of the (vertical) stratification of the top $0.2 \mathrm{~m}$ of the bed were made from a near-vertical section (scraped clean) of undisturbed box core sediment by pouring lacquer over the section, air-drying, carefully painting 


\section{Observations}

A Thickness of homogenous top layer Area 3

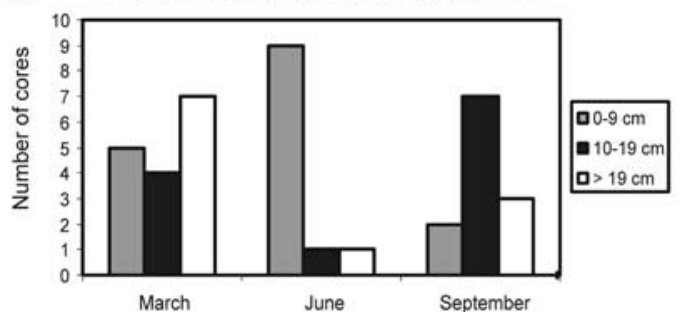

B

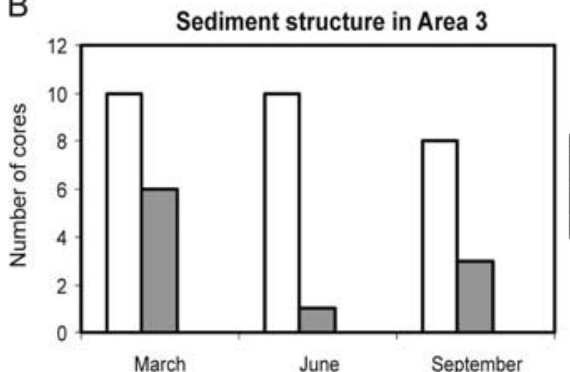

C Sedimentological features Area 3

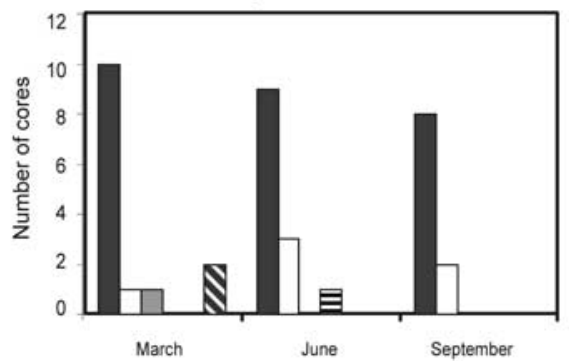

Representative graphic logs of split boxcores
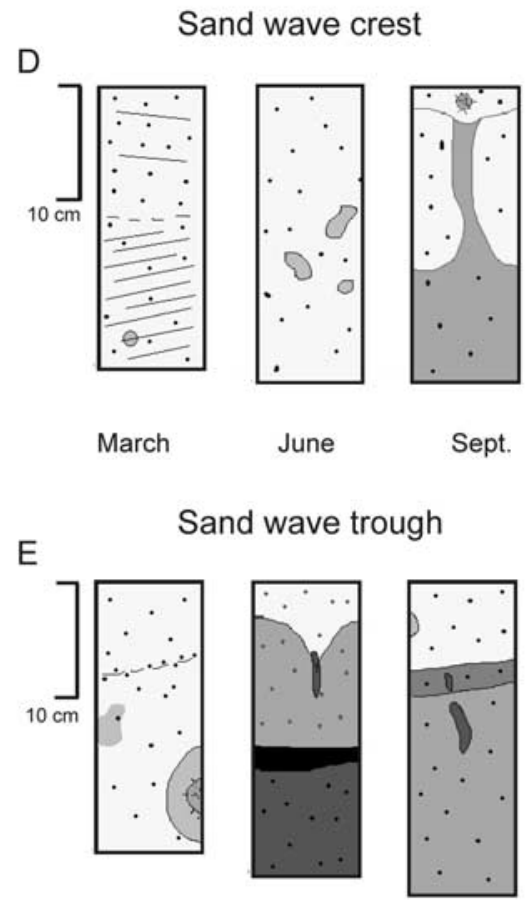

Legend

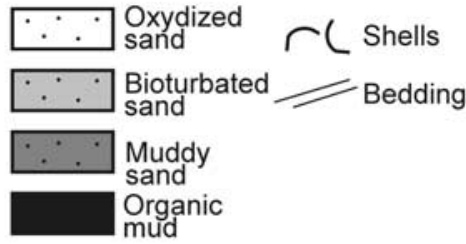

Figure 5. Sedimentology observed in $10 \mathrm{~cm}$ diameter split cores taken from box cores in the sand wave area (area 3). (a) Thickness of structureless top layer. (b) Sediment structure. Homogeneous is uniform lithological/sedimentological properties; stratified is more units with different lithological/sedimentological properties; deformed is one or more units with deformed bedding or deformed lithological contacts. (c) Sedimentological features recorded on the cut face of the cores. (d) Graphic logs for three samples from the same station on the crest of a sand wave. (e) Graphic logs for three samples from the same station in the trough of a sand wave.

cheese cloth on the lacquer, air-dry again and then gently pulling off the lacquered section.

\section{Results}

\subsection{Seabed Sediments}

[15] Both in area 1, across the shoreface-connected ridge, and in sand wave area 3 sediments consist of uniform, cross-bedded, and graded sands with shell fragments. No distinct differences in sediment composition were observed between the campaigns in 2001, but a spatial pattern related to ridge and sand wave morphology is apparent (Figures 4 and 5). Occasionally lags of coarser sand and shell frag- ments are encountered at the bed form crests. A spatial differentiation was also encountered in the grain size data (Figure 6).

[16] Seabed sediments in area 2 near Noordwijk are more variable in lithology and comprise uniform sands, shelly sands, and laminated sand and clay (Figure 7). Several cores collected in June and September 2001 had uniform, oxidized tops with polychaete tubes (Lanice conchilega) extending from the surface. The median grain size of sediments in the structureless "active" layer is lower in March than in June and September, when sediments are also more poorly sorted (Figure 8). Many cores collected after fair-weather and minor storm conditions in March and June 
Area 1
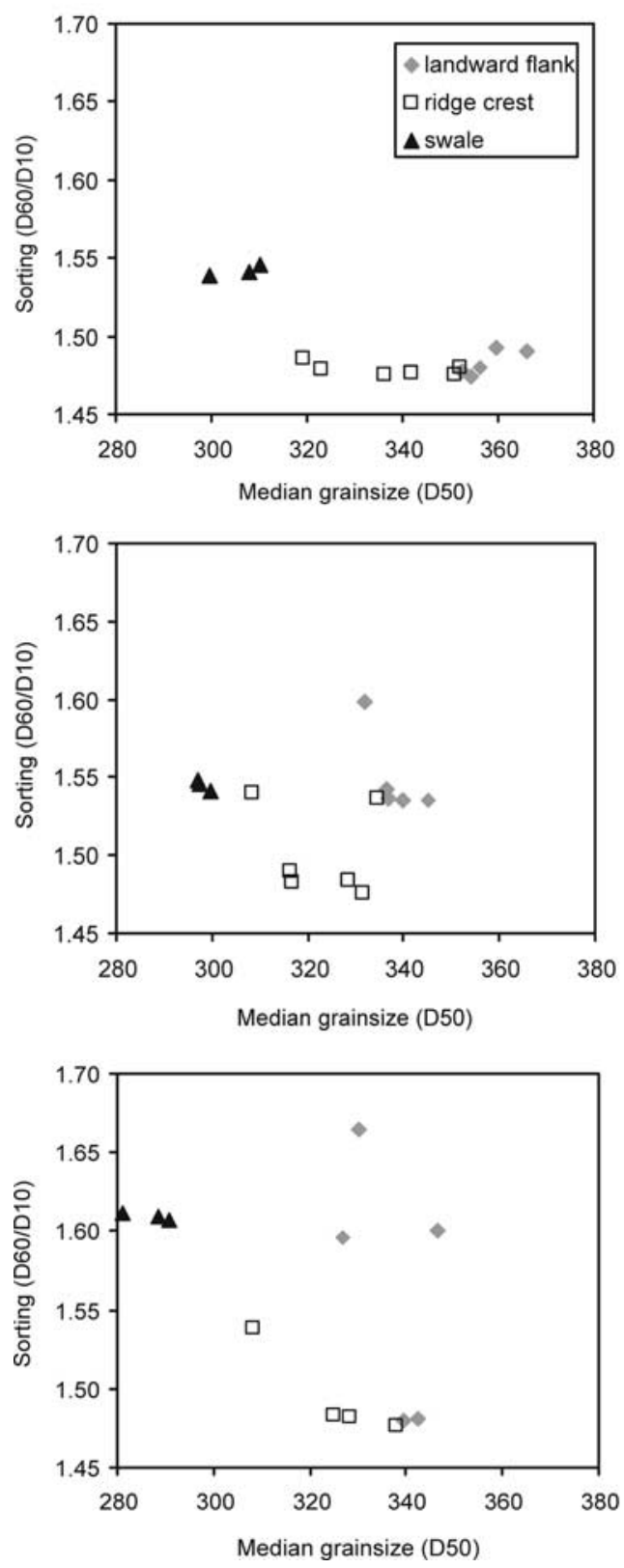

Area 3
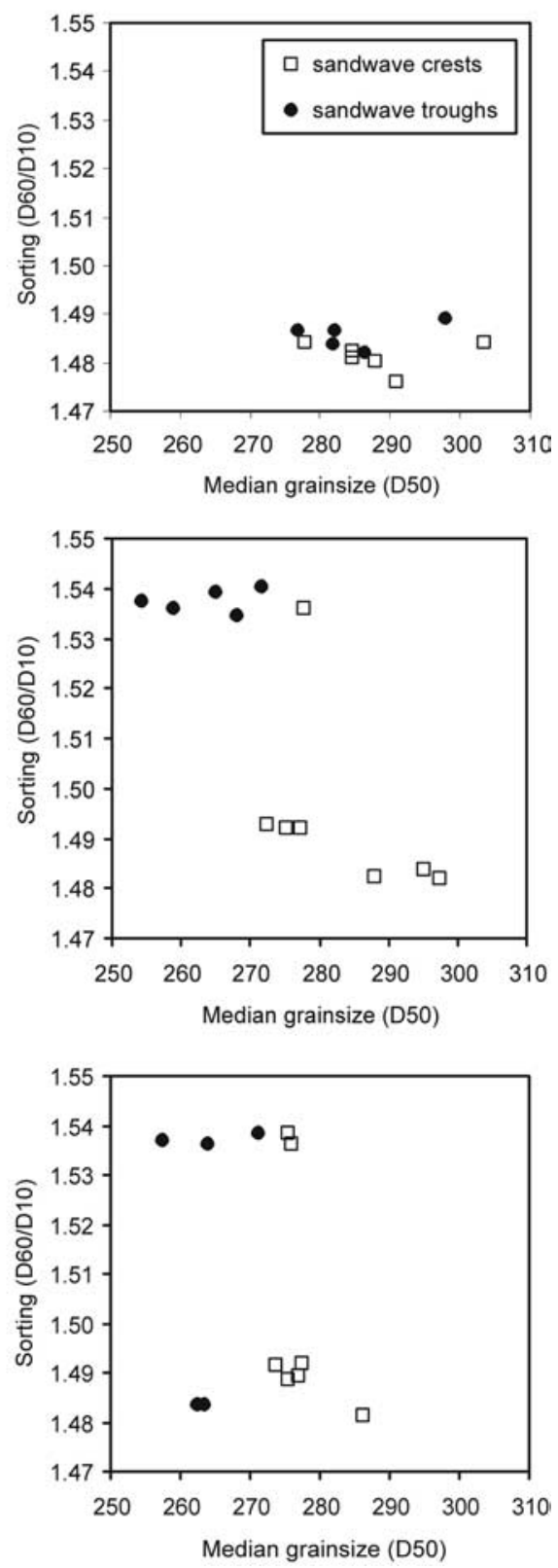

Figure 6. Bivariate plots of sorting $\left(\mathrm{D}_{60} / \mathrm{D}_{10}\right)$ and median grain size $\left(\mathrm{D}_{50}\right)$ in $\mu \mathrm{m}$. (left) Data for area 1 with the shoreface-connected ridge. (right) Data for area 3 with the sand waves.

displayed rhythmic centimeter-sized fine sand and clay laminations or flasers. Mud drapes were also encountered in box cores on the SANDPIT transect in September 2003 after fair-weather conditions (Figure 9). Poststorm in November 2002, however, 0.1-0.3 m thick sand beds with wave ripples and low-angle bedding were observed.

\subsection{Bed Form Morphology}

[17] The bed forms in area 3, offshore, appear uniform through the three surveys and consist of 2-D sand waves with superimposed 2-D megaripples (Figure 2). On the shoreface (area 1 and 2), bed forms show more variability within research areas and between surveys. Similar to the seabed sediments observed in the cores, in area 1 a spatial differentiation of bed form types is apparent, whereas bed forms appear more uniform in area 2 (Table 1). The bed forms in the three research areas can be classified as six different types with characteristic amplitude, wavelength and crest line orientations (Table 2). None of the observations yielded a plane bed in terms of seabed morphology. This is not surprising since plane bed is active during the peak of a storm and superimposed bed forms develop during the waning phase of a storm [Myrow and Southard, 1991; $\mathrm{Li}$ and Amos, 1999a].

\subsubsection{Two-Dimensional and Three-Dimensional Sand} Waves

[18] Asymmetric 3-D sand waves $(\lambda=700-800 \mathrm{~m}$; height $1.0-1.5 \mathrm{~m}$ ) on the crest of the shoreface-connected 


\section{Observations}

A Thickness of structureless top layer Area 2

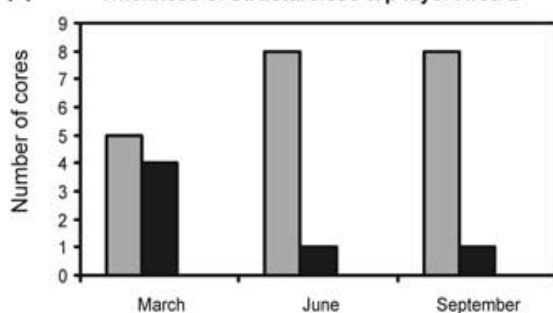

B

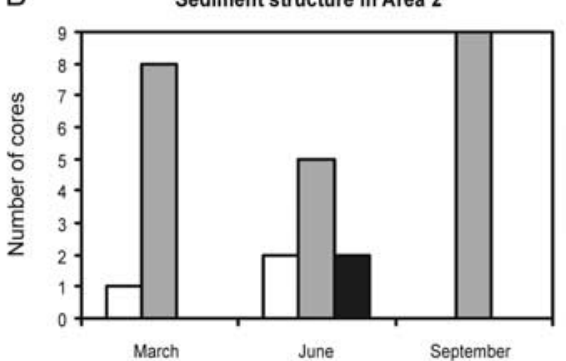

C Sedimentological features Area 2

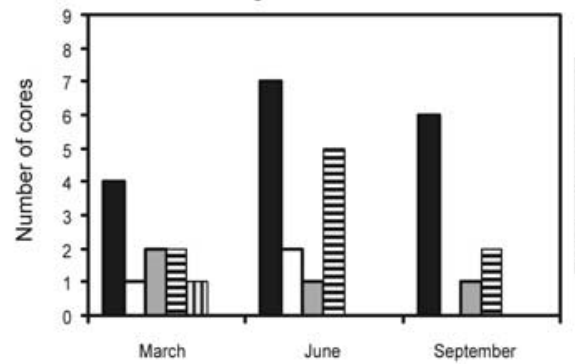

Representative graphic logs of split boxcores

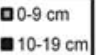

D> $19 \mathrm{~cm}$

ए>

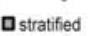

Deformed

\section{burrows}

D shell lags/clusters

Q horizontal bedding

E mud laminae

a flasers

\X-bedding
$\mathrm{D}$
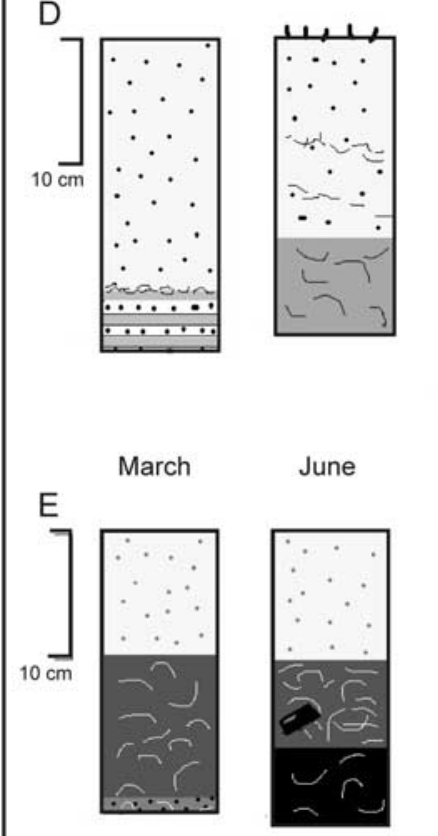

Legend

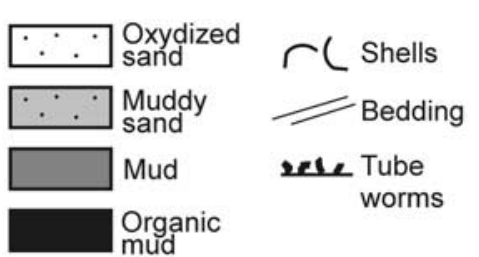

Figure 7. Sedimentology observed in $10 \mathrm{~cm}$ diameter split cores taken from box cores in area 2 on the shoreface. (a) Thickness of structureless top layer. (b) Sediment structure. Homogeneous is uniform lithological/sedimentological properties; stratified is more units with different lithological/sedimentological properties; deformed is one or more units with deformed bedding or deformed lithological contacts. (c) Sedimentological features recorded on the cut face of the cores. (d and e) Graphic logs for samples from two stations.

ridge in area 1 were present in all surveys. The morphology of the bed forms is visible in the bathymetric map of area 1 in Figure 1. Van de Meene [1994] also encountered these bed forms on single-beam echosounder tracks elsewhere on the same shoreface-connected ridge, and recorded wavelengths of $600-750 \mathrm{~m}$ and heights of $0.8-2 \mathrm{~m}$. The 2-D sand waves were observed in side-scan sonar records in the seaward swale of area 1 and in the multibeam data of the offshore sand wave area (area 3). The sand waves with amplitude $<1 \mathrm{~m}$ in area 1 are probably the marginal extension of the sand wave area present on the shelf [Terwindt, 1971; Van Alphen and Damoiseaux, 1989].

[19] Although the 3-D sand waves show minor, but significant northward migration of the lee slope [Van Dijk and Kleinhans, 2004], the morphology of the 2-D and 3-D sand waves is stable in the course of the measuring period and changes in morphology and position of transverse cross sections are generally within the limits of the standard error in the positioning (several meters) and bathymetry $(0.15 \mathrm{~m})$. The megaripples occur superimposed on these relatively stable bed forms.

\subsubsection{Two-Dimensional Megaripples}

[20] In area 3 (Figure 2), the sand wave area, 2-D megaripples with wavelength $10-15 \mathrm{~m}$ and amplitudes $<0.5 \mathrm{~m}$ were present superimposed on the sand waves during all surveys with not much variation in average wavelength or morphology. Crests of the megaripples are oriented transverse to the tidal flow with small deviations in 

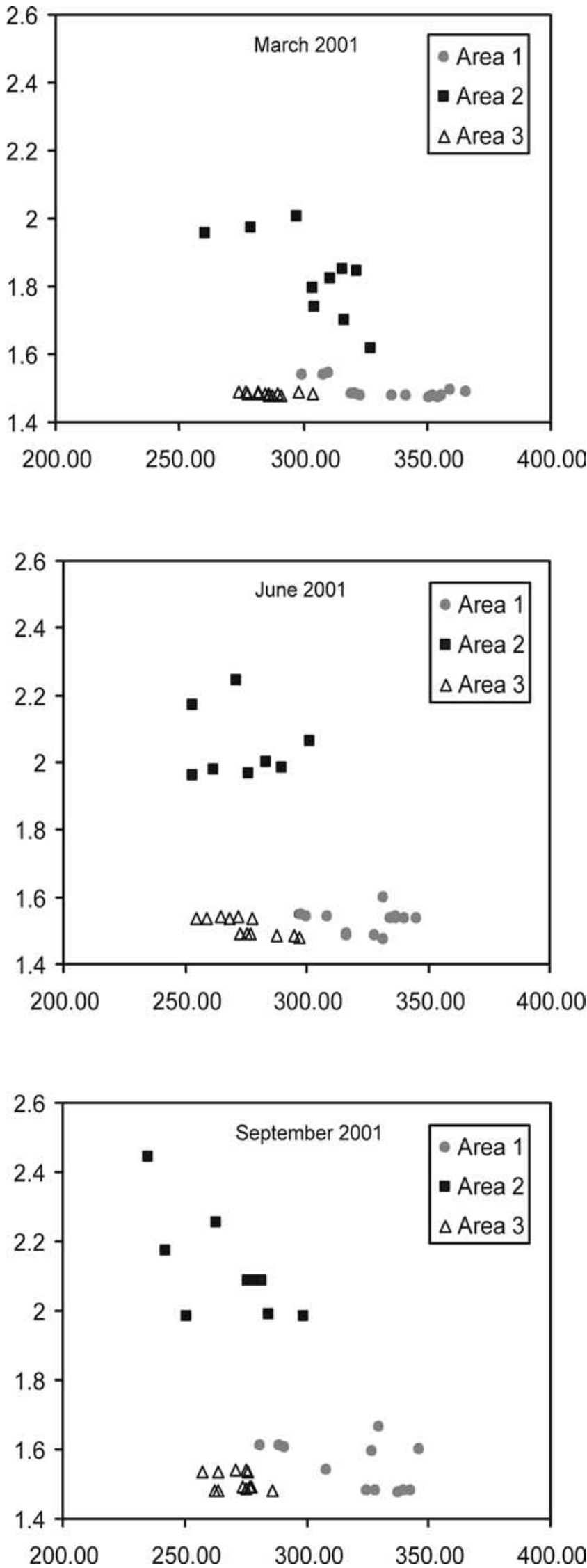

Figure 8. Bivariate plots of sorting $\left(\mathrm{D}_{60} / \mathrm{D}_{10}\right)$ and median grain size $\left(D_{50}\right)$ in $\mu \mathrm{m}$ for all three research areas. See Figure 1 for locations of research areas. orientation across the sand wave as was earlier observed elsewhere in the North Sea by Hennings et al. [2000]. On the shoreface, in shallower water depths asymmetrical 2-D megaripples $(\lambda=1-8 \mathrm{~m})$ are most prominent after longterm fair-weather conditions with average significant wave heights of $0.8 \mathrm{~m}$ and not exceeding $2.5 \mathrm{~m}$ (Figure 10). Large 2-D megaripples $(\lambda=20-40 \mathrm{~m})$ in an isolated depression in the seaward swale of area 1 cooccur with the smaller 2-D megaripples. Orientations of the 2-D megaripples are 100$132^{\circ} \mathrm{N}$, which is perpendicular to the maximum tidal flow direction. The 2-D megaripples are generally best developed in the seaward end of the research areas and fade in landward direction. Observations of side-scan sonar and multibeam images collected 1-2 weeks after a storm, which obliterated the megaripples, reveal that this type of 2-D megaripples had reappeared on the ridge crest within one spring-neap cycle. Sets of a different type of 2-D megaripples with crest line orientations of $10-82^{\circ} \mathrm{N}$, oblique to the direction of the coastline and the maximum tidal flow, were observed shortly after NW storms.

\subsubsection{Three-Dimensional Megaripples}

[21] Irregular 3-D megaripples $(\lambda=10-14 \mathrm{~m})$ were present in the swale of area 2 during all surveys in 2001. During the survey of 15-16 October 2001, after a SW storm of moderate intensity, the entire area 2 was covered with a complex weakly asymmetrical 3-D megaripple type $(\lambda=11-13 \mathrm{~m}$; Figure 11), that slightly increased in size in offshore direction. 3-D megaripples with shorter wavelengths $(5-8 \mathrm{~m})$ were present in the seaward swale of area 1 in two of the three surveys under lower-energy conditions.

[22] Mound-like 3-D megaripples of 20-40 m wavelength, and $0.15-0.25 \mathrm{~m}$ amplitude, are quite common on the shoreface (area 1 and area 2). However many times the bed forms are covered with smaller 2-D and 3-D megaripples $(\lambda<15 \mathrm{~m})$. The mound-like 3 -D megaripples are best preserved in the swale of area 2 and are frequently observed nearest to shore. In one occasion it was possible to relate this bed form type directly to specific wave conditions (Figure 12). At 9-10 July 2001, prior to a seasonal storm, the ridge crest and seaward area of the shoreface-connected ridge were surveyed by multibeam echosounder, but measurements were terminated because of the arrival of a storm with winds from the southwest $\left(\mathrm{H}_{\mathrm{sig}}>3 \mathrm{~m}\right.$; Figure 3$)$. The survey of the landward flank of the ridge was continued after the storm on 16-17 July. After the storm, the landward flank of the ridge was covered by mound-like 3-D bed forms, which were not present prior to the storm (Figure 12).

\section{Discussion}

\subsection{Stability Fields for Bed Forms}

[23] Sediment transport observations on the Dutch shoreface during spring tidal, fair-weather conditions by Van de Meene and van Rijn [2000] have shown that sediment transport rates (predominantly bed load) are very low and occur episodically during a period about 2 hours around maximum tidal flow. Measured near-bed $(0.45 \mathrm{~m})$ current velocities during fair-weather sediment transport were $>0.4 \mathrm{~m} / \mathrm{s}$. During seasonal storm events the current velocities on the Dutch coast are controlled by the wind speed and wind direction. During SW storms a 10-20\% increase of the flood current was observed [Van de Meene, 1994]. 


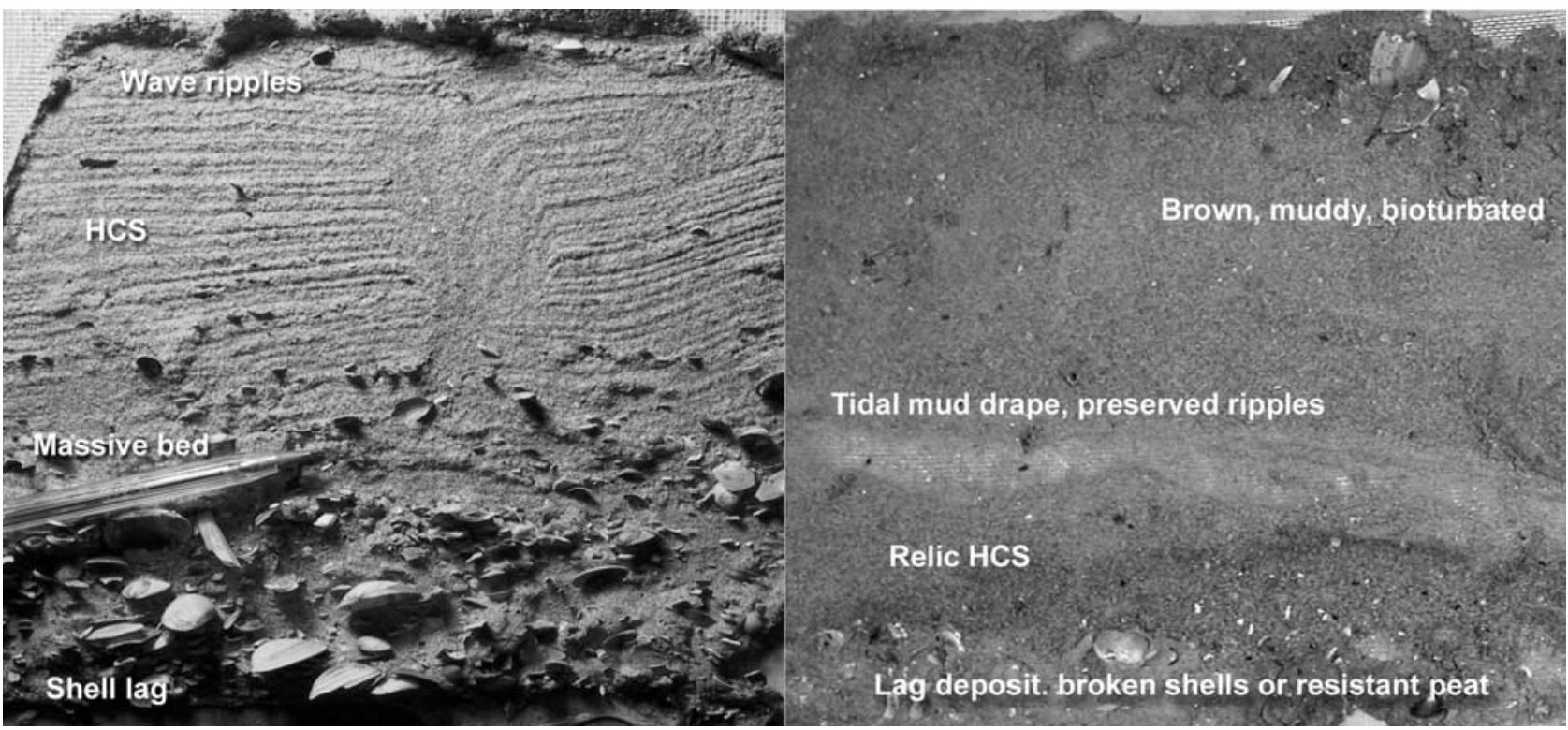

Figure 9. Lacquer profiles from box cores taken (left) on November 2002 (poststorm) at a water depth of $17 \mathrm{~m}$ and (right) on September 2003 (fair-weather conditions) at $12 \mathrm{~m}$ water depth. Figure 9 (left) represents a classical storm bed sequence deposited during the waning phase of a storm with decreasing energy from bottom to top. The HCS occurs in the upper part of the storm bed. Note pen on the left for scale (both pictures have the same scale).

SW is the dominant wind direction in the Southern Bight of the North Sea. However NW storms, although with lower frequency, cause higher storm surge levels (Figure 3). Coastal setup generally results in shore-parallel surface currents and in offshore directed bottom flows in response to the Coriolis force.

[24] A common classification for bed forms in unidirectional currents in order of increasing bed shear stress is lower plane bed, current ripples, dunes, and upper plane bed. The exact limits in terms of shear stress depend slightly on grain size [Southard and Boguchwal, 1990], but the differences in grain size between bed form obser- vations are small (range $\mathrm{D}_{50}=0.25-0.35 \mathrm{~mm}$ ). The data of the shoreface sites (areas 1 and 2) are plotted in bed form stability diagrams (Figure 13). Figure 13a relates the observed bed form types to current velocities. Unidirectional currents were estimated from the measurements of Van de Meene [1994]. The parameters relating to the images collected immediately after storm are calculated for the peak wave height of that storm. As a typical peak tidal current $0.5 \mathrm{~m} / \mathrm{s}$ was selected for fair-weather conditions, for SW storm conditions a measure of $0.6 \mathrm{~m} / \mathrm{s}$ was estimated and for NW storm with significant coastal setup ( $>0.4 \mathrm{~m} ;>48$ hours) a value of $0.7 \mathrm{~m} / \mathrm{s}$ was estimated. An

Table 1. Distribution of Bed Form Types, Wavelengths $(\lambda)$, and Crest Line Orientations Observed During the Monitoring Campaigns of 2001 in Areas 1 and 2 on the Dutch Lower Shoreface to Inner Shelf Transition (Water Depth 14-18 m) and in Area 3 on the Shelf (Water Depth $25-30 \mathrm{~m})^{\mathrm{a}}$

\begin{tabular}{|c|c|c|c|c|c|c|c|c|c|c|}
\hline \multicolumn{2}{|r|}{ Area } & \multicolumn{3}{|c|}{ Mar/Apr } & \multicolumn{3}{|c|}{ Jun/Jul } & \multicolumn{3}{|c|}{ Sep/Oct } \\
\hline Number & Section & $\begin{array}{c}\text { Bed Form } \\
\text { Type }\end{array}$ & $\lambda, \mathrm{m}$ & $\begin{array}{l}\text { Crest Line } \\
\text { Orientation }\end{array}$ & Bed Form Type & $\lambda, \mathrm{m}$ & $\begin{array}{l}\text { Crest Line } \\
\text { Orientation }\end{array}$ & $\begin{array}{c}\text { Bed Form } \\
\text { Type }\end{array}$ & $\lambda, \mathrm{m}$ & $\begin{array}{l}\text { Crest Line } \\
\text { Orientation }\end{array}$ \\
\hline 1 & landward swale & $\begin{array}{l}\text { mound-like } \\
\text { 3-D mr }\end{array}$ & $20-30$ & $\mathrm{n} / \mathrm{a}$ & $\begin{array}{c}\text { mound-like } \\
\text { 3-D mr }\end{array}$ & $20-30$ & $\mathrm{n} / \mathrm{a}$ & $\begin{array}{l}\text { mound-1. } \\
\text { 3-D mr }\end{array}$ & $20-30$ & $\mathrm{n} / \mathrm{a}$ \\
\hline 1 & landward swale & 2-D mr & $5-6$ & $100^{\circ} \mathrm{N}$ & & & & & & \\
\hline 1 & ridge crest & 3-D sw & $700-800$ & $102^{\circ} \mathrm{N}$ & 3-D sw & $700-800$ & $109^{\circ} \mathrm{N}$ & 3-D sw & $700-800$ & $105^{\circ} \mathrm{N}$ \\
\hline 1 & ridge crest & 2-D mr & $7-8$ & $105^{\circ} \mathrm{N}$ & 2-D mr & $4-6$ & $122^{\circ} \mathrm{N}$ & 2-D mr & $4-6$ & $82^{\circ} \mathrm{N}$ \\
\hline 1 & seaward swale & 2-D mr & $6-7$ & $102^{\circ} \mathrm{N}$ & 3-D mr & $7-8$ & $\mathrm{n} / \mathrm{a}$ & 3-D mr & $5-7$ & $\mathrm{n} / \mathrm{a}$ \\
\hline 1 & seaward swale & 2-D sw & $100-200$ & - & 2-D sw & $100-200$ & - & 2-D sw & $100-200$ & - \\
\hline 1 & seaward swale & 2-D mr & $20-30$ & $91^{\circ} \mathrm{N}$ & 2-D mr & $30-40$ & $107^{\circ} \mathrm{N}$ & & & \\
\hline 2 & lower shoreface & $\begin{array}{l}\text { mound-like } \\
\text { 3-D mr }\end{array}$ & $20-30$ & $\mathrm{n} / \mathrm{a}$ & $\begin{array}{c}\text { beam trawl } \\
\text { tracks }\end{array}$ & & & 3-D mr & $10-12$ & $\mathrm{n} / \mathrm{a}$ \\
\hline 2 & inner shelf & $\begin{array}{l}\text { mound-like } \\
\text { 3-D mr }\end{array}$ & $30-40$ & $\mathrm{n} / \mathrm{a}$ & $\begin{array}{c}\text { mound-like } \\
\text { 3-D mr }\end{array}$ & $30-40$ & $\mathrm{n} / \mathrm{a}$ & & & \\
\hline 2 & inner shelf & 2-D mr & $4-8$ & $132^{\circ} \mathrm{N}$ & & & & & & \\
\hline 2 & inner shelf & 3-D mr & $12-14$ & $\mathrm{n} / \mathrm{a}$ & 3-D mr & $12-14$ & $\mathrm{n} / \mathrm{a}$ & 3-D mr & $11-13$ & $\mathrm{n} / \mathrm{a}$ \\
\hline 3 & shelf & $2-\mathrm{D}$ sw & 200 & $95^{\circ} \mathrm{N}$ & $2-\mathrm{D} \mathrm{sw}$ & 200 & $95^{\circ} \mathrm{N}$ & $2-\mathrm{D} \mathrm{sw}$ & 200 & $95^{\circ} \mathrm{N}$ \\
\hline 3 & shelf & 2-D mr & $10-15$ & $120^{\circ} \mathrm{N}$ & 2-D mr & $10-15$ & $120^{\circ} \mathrm{N}$ & 2-D mr & $10-15$ & $120^{\circ} \mathrm{N}$ \\
\hline
\end{tabular}

${ }^{a}$ Here $\mathrm{mr}$ is megaripples, and sw is sand waves. 
Table 2. Classification of Bed Form Types on the Dutch Lower Shoreface and Shelf Observed During the Monitoring Campaigns of 2001, 2002, and 2003

\begin{tabular}{llll}
\hline Bed Form Type & Wavelength & Height & \multicolumn{1}{c}{$\begin{array}{l}\text { Crest Line } \\
\text { Orientation }\end{array}$} \\
\hline 2-D megaripples & $1-40 \mathrm{~m}$ & $\mathrm{~cm} / \mathrm{dm}$ & $91-132^{\circ} \mathrm{N}$ \\
2-D megaripples & $5-15 \mathrm{~m}$ & $\mathrm{dm}$ & $10-81^{\circ} \mathrm{N}$ \\
3-D megaripples & $5-15 \mathrm{~m}$ & $\mathrm{dm}$ & - \\
$\begin{array}{c}\text { Mound-like 3-D } \\
\text { megaripples }\end{array}$ & $20-40 \mathrm{~m}$ & $\mathrm{dm}$ & - \\
2-D sand waves & $100-200 \mathrm{~m}$ & $<1-3 \mathrm{~m}$ & $90-95^{\circ} \mathrm{N}$ \\
3-D sand waves & $700-800 \mathrm{~m}$ & $1-1.5 \mathrm{~m}$ & $102-109^{\circ} \mathrm{N}$ \\
\hline
\end{tabular}

increase of $0.1 \mathrm{~m} / \mathrm{s}$ was added for spring flood conditions. These estimates should be regarded as the maximum current velocities; the actual unidirectional velocities for the equilibrium bed forms may be lower. Orbital velocities were calculated from linear theory using significant wave heights $\mathrm{H}_{\mathrm{sig}}$ and periods $\mathrm{T}_{\mathrm{p}}$ from station IJmuiden Munitiestortplaats (water depth $21 \mathrm{~m}$ ) for bed forms in area 1 and from station Meetpost Noordwijk (water depth $18 \mathrm{~m}$ ) for area 2. The accuracy of the wave parameters is a relative standard deviation of $5 \%$ for $\mathrm{H}_{\text {sig }}$ and $2.5 \%$ for $\mathrm{T}_{\mathrm{p}}$. The maximum significant wave heights and wave periods within one spring-neap cycle prior to data collection were used. For bed forms developing in the waning phases of storms the actual oscillatory flows may be lower. Observations and flow conditions are listed in Table 3.

[25] The dimensionless (Shields) shear stress parameter is also computed and plotted in Figure 13b, ignoring their different directions:

$$
\theta=\tau /\left[\left(\rho_{\text {sed }}-\rho_{\text {water }}\right) \mathrm{gD}_{50}\right]
$$

with

$$
\tau=\rho_{\text {water }} \mathrm{g}\left[\mathrm{U}_{\text {cur }} / 18^{10} \log \left(12 \mathrm{~h} / 2.5 \mathrm{D}_{50}\right)\right]^{2}
$$

for currents and

$$
\tau=\rho_{\text {water }} \mathrm{U}_{\text {orb }, \text { sig }}^{2} \exp \left[5.213\left(2.5 \mathrm{D}_{50} / \mathrm{A}_{\text {orb }, \text { sig }}\right)^{0.194}-5.977\right]
$$

for waves, with $\tau=$ shear stress, $\mathrm{g}=9.81 \mathrm{~m} \mathrm{~s}^{-2}, \mathrm{~h}=$ local water depth, $\mathrm{D}_{50}=$ local median sediment diameter, and $\mathrm{U}_{\text {orb }}=$ significant orbital velocity, and $\mathrm{U}_{\text {cur }}=$ significant current velocity, $A_{\text {orb,sig }}=$ significant orbital semidiameter, and $\rho_{\text {water }}=1025 \mathrm{~kg} / \mathrm{m}^{3}$ and $\rho_{\text {sed }}=2650 \mathrm{~kg} / \mathrm{m}^{3}$.

\subsection{Current Megaripples}

[26] Two types of 2-D megaripples were observed after different meteorological conditions which are distinguished based on crest line orientations (Figure 13). In the velocity diagram the 2-D megaripples with crest orientations 91$132^{\circ} \mathrm{N}$ during fair-weather conditions plot at oscillatory currents $<0.15 \mathrm{~m} / \mathrm{s}$. The crest line orientations and wavelength/water depth ratios $(0.3-0.5)$ of these 2-D megaripples correspond to those of megaripples observed below wave base on the shelf, where the tidal flow regime is dominant (area 3). On the basis of their crest line orientation perpendicular to the direction of the maximum tidal flow we consider these megaripples as tidal current dunes

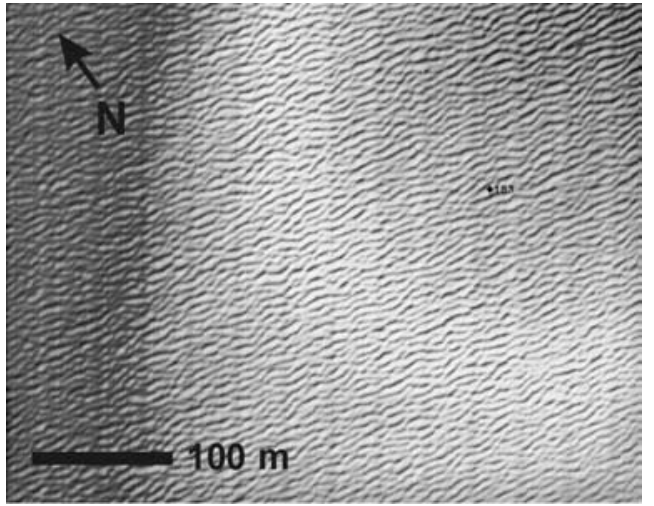

Figure 10. Multibeam image processed with oblique illumination of 2-D megaripples (wavelength 5-7 m) on the shoreface-connected ridge (area 1) in a fair-weather period (data collected March 2001). Vertical striping is an artifact of data acquisition and reflects the orientation of the multibeam tracks.

(Figure 13). Similar to Van de Meene et al. [1996] we observed an increase in low-angle and horizontal bedding in the shoreward direction coinciding with fading of 2-D megaripples, indicating a shoreward increase of the overall influence of wave-induced oscillatory flows. We therefore conclude that the boundary for the stability of the 2-D current megaripples is at oscillatory flows of $0.15 \mathrm{~m} / \mathrm{s}$. The 2-D megaripples at $10-82^{\circ} \mathrm{N}$ crest line orientations observed after NW storm conditions are not transverse to the maximum tidal flow direction. These megaripples are associated with significant coastal setup and probably formed in response to an offshore bottom current in the later phase of the storms.

[27] In a morphodynamic model of Idier and Astruc [2004], with physical parameters comparable to the ones used in this study, dominant factors in the generation of megaripples from the coast in offshore direction were grain

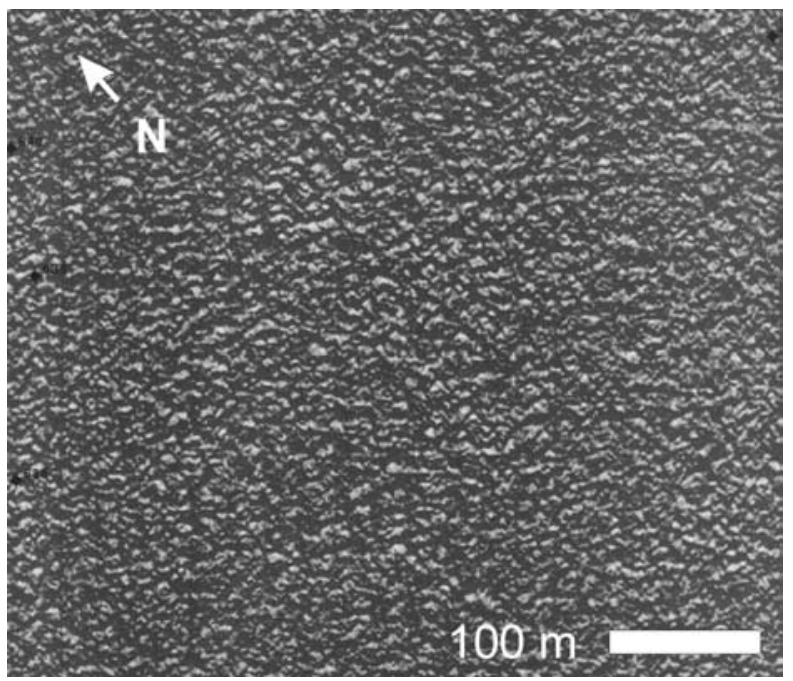

Figure 11. Three-dimensional megaripples in multibeam image with oblique illumination of the seaward swale of area 2 after a seasonal storm of moderate intensity (data collected October 2001). 

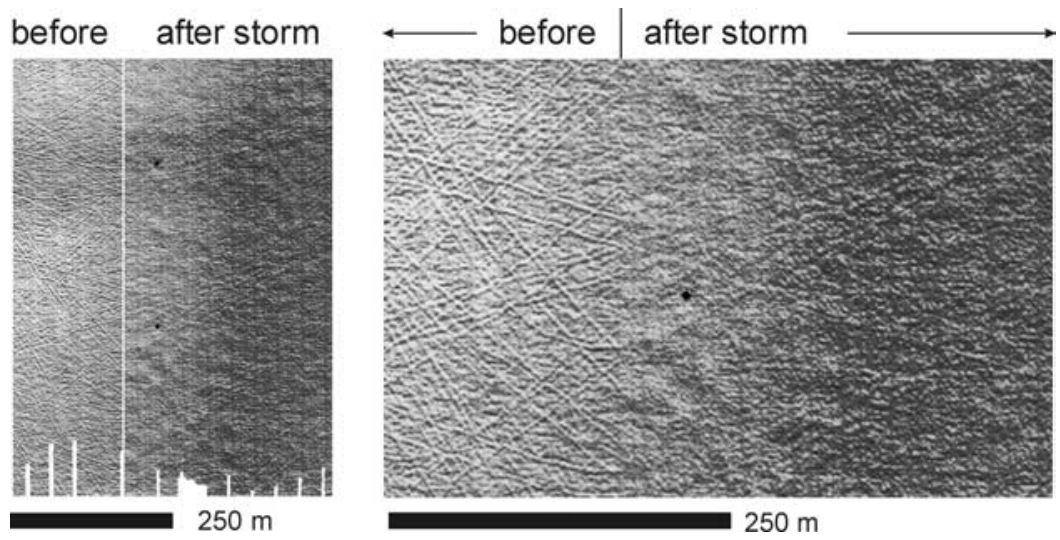

Figure 12. Multibeam swath bathymetry of part of area 1 with artificial oblique illumination, based on data collected 9-10 and 16-17 July, before and after a SW storm of moderate intensity (see Figure 2). The images display parts of the same area at different scales. Dots are box core sample locations. Note beam trawl tracks on the left side of both images prior to the storm. On the right of the images, moundlike 3-D megaripples have developed with superimposed 3-D megaripples of a shorter wavelength after the storm.

roughness $(15 \mathrm{~m})$, surface waves $(17 \mathrm{~m})$, ripples $(24 \mathrm{~m})$, and ripples, megaripples, or sand waves combined with wave action $(>30 \mathrm{~m})$. In our study, data resolution was not sufficient to demonstrate the presence or absence of ripples, although they have been observed on other continental shelves [Field et al., 1981]. The presence of megaripples in the absence of sand waves (area 2) in shallow nearshore settings is in agreement with the results of the modeling study [Idier and Astruc, 2004], that predicts megaripples of $20 \mathrm{~m}$ wavelengths in this setting. However, the long mega- ripples of $>20 \mathrm{~m}$ wavelength that we observed are 3-D mound-like megaripples that develop during seasonal storm wave conditions, whereas the fair-weather megaripples in area 2 have shorter wavelengths $(4-8 \mathrm{~m})$.

\subsection{Hummocks and 3-D Megaripples}

[28] In this study small 3-D megaripples $(\lambda=5-15 \mathrm{~m})$ are the most dominant bed forms on the shoreface (Table 2). After storms of moderate to high energy the 3-D megaripples are superimposed on large mound-like bed forms
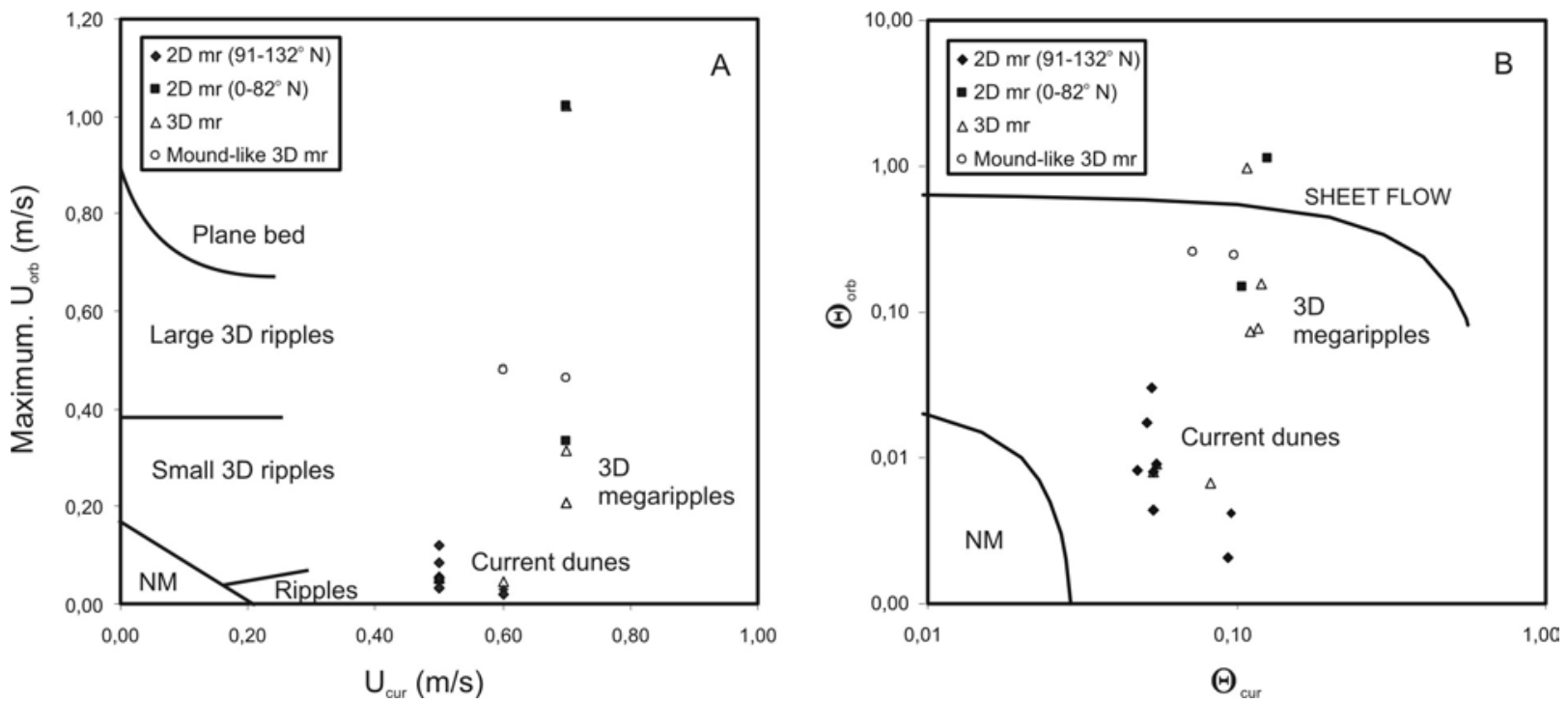

Figure 13. Bed form types in medium sand observed in 2001 in areas 1 and 2 presented in bed form stability diagrams on the basis of (a) current velocities and (b) dimensionless Shields shear stress parameters. Orbital velocities were calculated using linear wave theory and data from the MPN and YM6 measuring stations (source is Golfklimaat, http://www.golfklimaat.nl, data listed in Table 3.). Unidirectional velocities are maximum velocities estimated on the basis of measurements of Van de Meene [1994]. Solid lines in Figure 13a represent the bed phases defined based on flow-duct experiments in fine sand [Arnott and Southard, 1990]. Solid lines in Figure 13b are the thresholds for motion $\left(\theta_{\mathrm{cr}}=\right.$ $\left.\theta_{\text {orb }}+\theta_{\text {cur }}=0.03\right)$ and sheet flow $\left(\theta_{\text {sf }}=\theta_{\text {orb }}+\theta_{\text {cur }}=0.64\right)$. The latter is calculated on the basis of work by Li and Amos [1999b]: $\theta_{\mathrm{sf}}=0.172 \mathrm{D}^{-0.376}=0.64$ for $0.3 \mathrm{~mm}$ sand. NM, no motion; mr, megaripple. 
Table 3. Data Used to Create Figure $13^{\mathrm{a}}$

\begin{tabular}{lccccccc}
$\begin{array}{c}\text { Megaripple } \\
\text { Type }\end{array}$ & $\begin{array}{c}\text { Wavelength, } \\
\mathrm{m}\end{array}$ & $\begin{array}{c}\mathrm{h}, \\
\mathrm{m}\end{array}$ & $\begin{array}{c}\mathrm{D}_{50}, \\
\mu \mathrm{m}\end{array}$ & $\begin{array}{c}\mathrm{H}_{\text {sig, }}, \\
\mathrm{m}\end{array}$ & $\begin{array}{c}\mathrm{T}_{\mathrm{p}}, \\
\mathrm{s}\end{array}$ & $\begin{array}{r}\mathrm{U}_{\text {cur, }}, \\
\mathrm{m} / \mathrm{s}\end{array}$ & $\begin{array}{c}\mathrm{U}_{\text {orb }}, \\
\mathrm{m} / \mathrm{s}\end{array}$ \\
\hline Mound-like 3-D & $20-30$ & 16 & 338 & 3.2 & 5.9 & 0.6 & 0.48 \\
Mound-like 3-D & $20-30$ & 16 & 337 & 3.1 & 5.9 & 0.7 & 0.46 \\
2-D & $20-30$ & 18 & 306 & 1.6 & 4.1 & 0.5 & 0.03 \\
2-D & $30-40$ & 18 & 298 & 1.6 & 4.4 & 0.5 & 0.05 \\
2-D & $5-6$ & 16 & 358 & 1.6 & 4.1 & 0.5 & 0.05 \\
2-D & $7-8$ & 14 & 337 & 1.6 & 4.1 & 0.5 & 0.08 \\
2-D & $4-6$ & 14 & 323 & 1.6 & 4.4 & 0.5 & 0.12 \\
2-D & $4-6$ & 14 & 325 & 2.1 & 5.5 & 0.7 & 0.33 \\
2-D & $6-7$ & 18 & 306 & 1.6 & 4.1 & 0.5 & 0.03 \\
2-D & $4-8$ & 18 & 303 & 1.3 & 4.5 & 0.5 & 0.05 \\
3-D & $7-8$ & 18 & 298 & 1.6 & 4.4 & 0.5 & 0.05 \\
3-D & $5-7$ & 18 & 287 & 2.1 & 5.5 & 0.7 & 0.21 \\
3-D & $10-12$ & 15 & 268 & 2.6 & 5.2 & 0.7 & 0.31 \\
3-D & $12-14$ & 18 & 303 & 1.3 & 4.5 & 0.5 & 0.05 \\
3-D & $12-14$ & 18 & 282 & 1.3 & 4.4 & 0.6 & 0.04 \\
3-D & $11-13$ & 18 & 268 & 2.6 & 5.2 & 0.7 & 0.21 \\
\hline
\end{tabular}

${ }^{\mathrm{a}}$ Megaripple types, megaripple wavelengths, and water depths were derived from the multibeam data, grain sizes were measured on samples from box cores, and significant wave height $\left(\mathrm{H}_{\mathrm{sig}}\right)$ and wave period $\left(\mathrm{T}_{\mathrm{p}}\right)$ were derived from measuring stations Meetpost Noordwijk $(\mathrm{h}=18 \mathrm{~m})$ and IJmuiden Munitiestortplaats ( $\mathrm{h}=21 \mathrm{~m}$ ) (available from http:// www.golfklimaat.nl). $\mathrm{U}_{\text {cur }}$ is estimated on the basis of measurements of Van de Meene [1994], and $\mathrm{U}_{\text {orb }}$ is calculated using linear wave theory. Wave parameters were based on surface wave measurements.

$(\lambda=20-30 \mathrm{~m})$, when low-angle bedding with converging laminae is observed in box cores. Notable is that the 3-D megaripples of wavelength $5-15 \mathrm{~m}$ are also observed in low-energy conditions, when the critical oscillatory flow velocities for the formation of the mound-like 3-D bed forms are not reached. Most scientists accept the interpretation that 3-D ripples occur under larger flows than 2-D forms for a given depth and grain size [Southard and Boguchwal, 1990; Ashley et al., 1990]. However, opinions vary as to the contribution of oscillatory flows in the formation of different types of 3-D megaripples. Figure 13 shows that small 3-D megaripples develop at slightly larger flows than 2-D megaripples but that the stability fields overlap. These bed forms with similar wavelengths of $1-15 \mathrm{~m}$ form a continuum with an upper stability boundary of oscillatory flows of $0.15 \mathrm{~m} / \mathrm{s}$ for the 2-D megaripples. In contrast, the low-angle mound-like 3-D bed forms with spacing 20-30 $\mathrm{m}$ and amplitude of $0.15-$ $0.25 \mathrm{~m}$ have only been observed to occur at oscillatory flows $>0.4 \mathrm{~m} / \mathrm{s}$ (Figure 13a).

[29] The bed structure of Figure 9, generated after a seasonal storm, has a fourfold bed subdivision that can be interpreted as erosion and deposition under waning oscillatory flows [Myrow and Southard, 1991] as a lower erosional phase (1) generating a shell lag, (2) deposition of a massive bed through sheet flow and sediment settling in waning oscillatory flow conditions, (3) low-angle bedding with converging laminae, interpreted as hummocky cross stratification, generated in combined flow conditions, and (4) small 2-D ripples generated in the end phase of the storm. The multibeam data show that the undulating bed topography develops when oscillatory velocities exceed $0.4 \mathrm{~m} / \mathrm{s}$, whereas the superimposed 3-D megaripples develop at lower flow velocities, such as in the waning phase of a storm. Therefore the massive bed (2) probably corresponds to the undulating topography, whereas the HCS (3) corresponds to the small 3-D megaripples. The thickness of low-angle beds is $0.1-0.3 \mathrm{~m}$, and the hypothesis that one set of HCS can be created in one event [Greenwood and Sherman, 1986; Van de Meene et al., 1996; Amos et al., 1996] is corroborated with the present box cores. However, some box cores only yielded an erosional surface with a shell lag, suggesting that hummocks are not evenly distributed. Moreover, on the Dutch coast, the net settling of sediment in waning storms is an order of magnitude smaller than the $0.1 \mathrm{~m}$ thickness of the storm bed, based on typical concentrations during storms [Grasmeijer et al., 2005]. Therefore, given the fact that both types of 3-D megaripples develop near sheet flow conditions, the bed forms are probably partially attained by local redistribution of sediment.

[30] In flow duct experiments, bed form spacing increases dramatically with increasing oscillatory currents [Arnott and Southard, 1990]. In purely oscillatory flow of $0.4-0.8 \mathrm{~m} / \mathrm{s}$, the 3-D ripples were characterized as symmetrical undulating bed topography, associated with plane bed conditions. In our study, the large mound-like 3 -D bed forms $(\lambda=20-$ $30 \mathrm{~m}$ ) are observed when the flow velocities reach the oscillatory sheet flow boundary (Figure 13). Although the laboratory setting cannot be compared quantitatively to the field situation due to scale differences, these field observations also suggest that increasing length scales are associated with increasing wave energy at the bed. In addition, a smoothing of large bed forms near the threshold to sheet flow is similar to laboratory observations.

\subsection{Megaripples and Sand Waves}

[31] The meter-scale change in sand wave morphology and crest position relative to a meter-scale measurement uncertainty, indicate that small seasonal storms do not have a measurable effect on these large bed forms at short timescales. This is in agreement with modeled sand wave migration rates of 5-10 m/yr [Németh et al., 2002] and previous field studies, where abrupt modifications of sand wave morphology, including flattening of sand wave crests, and changes in crest position are mainly attributed to more intense wind and wave conditions [Terwindt, 1971; Field et al., 1981; Langhorne, 1982; Houthuys et al., 1994].

[32] Terwindt [1971] previously pointed out the cresttrough variability in grain size for sand waves in the North Sea, but a clear connection with hydrodynamic conditions could not be indicated. Here a fining of 2-D sand wave troughs offshore was observed after seasonal storms in June and September relative to the fair-weather situation in March (Figure 6), whereas sand wave crests showed little change in grain size properties. Hennings et al. [2000] found maximum current velocities and wave energy density at 2-D sand wave crests on the North Sea shelf and minima in the troughs. Although a role for seasonal changes in macrobenthos distribution and bioturbation cannot be ruled out, the fining of the troughs could also be a result of deposition of fines after storms, whereas stronger currents and wave action winnow fines at sand wave crests.

[33] On the shoreface (area 1) mound-like 3-D megaripples and smaller 3-D megaripples occur superimposed on the flat-topped 3-D sand waves after seasonal storms, but 2-D megaripples dominate after a fair-weather period. Offshore (area 3) only 2-D megaripples are observed as superimposed bed forms during all surveys. Offshore, 2-D megaripples increase in wavelength toward the 2-D sand 
wave crests, but this is not obvious on the 3-D sand waves in the shoreface setting. Orientations of 2-D megaripple crests deviate $20-30^{\circ}$ clockwise from sand wave crest orientations in the offshore area (area 3 ), and $3-15^{\circ}$ clockwise in the shoreface area (area 1). This could be related to differences in the stoss slope angle of the sand waves [Hennings et al., 2000], which is lower for the 3-D sand waves.

[34] In all surveys, the 2-D sand waves offshore that are generated by tidal current flow [Hulscher, 1996] have superimposed 2-D megaripples, interpreted as tidal current dunes (see previous section). The 2-D sand waves therefore likely form compound bed forms of 2-D tidal current megaripples. This is in agreement with observations of the internal architecture of 2-D sand waves in the North Sea (TNO, unpublished data, 2002). In contrast, the complex $3-\mathrm{D}$ geometry of the sand waves on the shoreface and the superimposed 3-D megaripples during storm events suggest that these sand waves are compound bed forms of combined flow megaripples, such as hummocks. This is in agreement with observations of outcrop studies by, for example, Mitgaard [1996], where several beds of hummocky cross stratification are observed within larger-scale units of $>15 \mathrm{~m}$ wavelength.

\subsection{Macrobenthic Controls on Bed Form Development}

[35] Hydrodynamics are the primary control on bed form development, but local differences in morphological, sedimentological and benthic boundary layer characteristics may also influence size, geometry, and preservation of bed forms. In contrast to area 1 and area 3 , in area 2 mud laminae and flasers make up a large proportion of the upper decimeters of the seabed and the active sand layer at the top is relatively thin, generally $<0.1 \mathrm{~m}$, especially during fairweather conditions (Figure 5). In June and September 2001 bed forms in area 2 and the swale of area 1 are absent or poorly developed (Table 1), while the surficial sediments during this period are finer and more poorly sorted (Figure 4). Although these observations may have a number of causes, it is interesting to note that tube worm communities of Lanice conchilega are prominent in area 2 in June and September 2001. Lanice conchilega worms build tubes of sand grains that extend several $\mathrm{cm}$ above the seafloor. These worm tubes and similar biogenic structures extending upward from the seabed are known to influence the properties of the benthic boundary layer and to enhance sedimentation through trapping of finegrained particles [Carey, 1987; De Falco et al., 2000]. Therefore further studies on bed form development in this area should include the influence of Lanice conchilega on sediment composition and on the properties of the benthic boundary layer under a range of flow conditions.

\section{Conclusions}

[36] The influence of seasonal storm events and fairweather periods on the stability of large-scale compound bed forms is investigated here. In medium sands (median grain size $0.25-0.35 \mathrm{~mm}$ ) on the Dutch lower shoreface megaripples of distinct morphology develop in response to specific hydrodynamic conditions. Multibeam and side-scan sonar surveys show that 2-D megaripples $(\lambda=1-15 \mathrm{~m})$ are the dominant bed forms on the lower shoreface and the shelf in current-dominated $(>0.4 \mathrm{~m} / \mathrm{s})$ tidal flow regimes with oscillatory flows $<0.15 \mathrm{~m} / \mathrm{s}$. Under these conditions, tubebuilding Lanice conchilega communities may locally be responsible for an increase in mud deposition, which influences megaripple development. In slightly higher energy conditions, with stronger currents and wave stirring, small 3-D megaripples $(\lambda=5-15 \mathrm{~m})$ begin to develop. The 2-D and 3-D megaripples have similar wavelengths (1$15 \mathrm{~m}$ ) and form a continuum in increasing current strengths with oscillatory flows of $0.15 \mathrm{~m} / \mathrm{s}$ as the upper boundary for the stability of 2-D megaripples. During storms, at oscillatory flows $>0.4 \mathrm{~m} / \mathrm{s}$ an undulating bed topography consisting of mound-like 3-D bed forms (20-40 m) develops that is covered by smaller $3-\mathrm{D}$ megaripples $(<15 \mathrm{~m})$ after the storm. The bed structure in box cores demonstrates that the undulating topography corresponds to the formation of a massive bed through erosion and sediment redistribution in sheet flow conditions. The superimposed small 3-D megaripples are related to low-angle bedding, interpreted as hummocky cross stratification, representing bed form migration and aggradation in combined flow conditions during the waning phases of these storms.

[37] Multiple seasonal storm events of low intensity do not have a measurable effect on sand wave morphology or position. Offshore, on the inner shelf, 2-D megaripples are dominant on 2-D sand waves with little change in megaripple dimension and distribution in response to small seasonal storms. The 2-D sand waves form compound bed forms of 2-D tidal current megaripples. On the shoreface $3-\mathrm{D}$ sand waves are covered by $3-\mathrm{D}$ megaripples during seasonal storms. The flat-topped $3-\mathrm{D}$ sand waves form compound bed forms of both 2-D megaripples, and 3-D megaripples or hummocks that are active under storminfluenced combined flow conditions.

\section{Notation \\ $\mathrm{A}_{\text {orb,sig }}$ significant orbital semidiameter (m). \\ $\mathrm{D}_{50}$ median grain diameter $(\mathrm{mm})$. \\ $\mathrm{D}_{60} / \mathrm{D}_{10}$ uniformity coefficient. \\ $\mathrm{g}$ acceleration due to gravity $\left(9.81 \mathrm{~m} \mathrm{~s}^{-2}\right)$. \\ $\mathrm{h}$ local water depth (m). \\ $\mathrm{H}_{\text {sig }}$ significant wave height (m). \\ $\mathrm{T}_{\mathrm{p}}$ significant wave period ( $\mathrm{s}$ ). \\ $\mathrm{U}_{\text {cur }}$ significant current velocity $(\mathrm{m} / \mathrm{s})$. \\ $\mathrm{U}_{\text {orb }}$ significant orbital velocity $(\mathrm{m} / \mathrm{s})$. \\ $\lambda$ wavelength (m) of bed form. \\ $\tau$ shear stress. \\ $\rho_{\text {water }}$ density of water $\left(1025 \mathrm{~kg} / \mathrm{m}^{3}\right)$ \\ $\rho_{\text {sed }}$ density of sediment $\left(2650 \mathrm{~kg} / \mathrm{m}^{3}\right)$. \\ $\theta_{\text {cr }}$ critical dimensionless Shields shear-stress para- meter for motion. \\ $\theta_{\text {orb }}$ dimensionless Shields shear-stress parameter for orbital flow. \\ $\theta_{\text {cur }}$ dimensionless Shields shear-stress parameter for currents. \\ $\theta_{\text {sf }}$ critical dimensionless Shields shear-stress param- eter for sheet flow.}

[38] Acknowledgments. This study was conducted with data collected within the projects "Ecomorphodynamics of the seafloor," part of the Coast and River section within the Delft Cluster framework, and the 
European "SANDPIT" project (funded by EC MAST, MAS3-CT97-0086). The North Sea Directorate (RWS-DNZ) and the National Institute for Coastal and Marine Management (RWS-RIKZ), both of the Dutch Directorate General for Public Works and Water Management, are thanked for constructive cooperation in data collection and processing, particularly Simon Bicknese, Rob Lambij, René van der Aar, and the crews of the vessels Arca, Zirfaea, Mitra, and Rotterdam. This work will contribute to the MESH project (Mapping European Seabed Habitats, http://www.searchmesh.net) and received European Regional Development Funding through the INTERREG III B Community Initiative (http://www.nweurope.org)

\section{References}

Amos, C. L., M. Z. Li, and K. S. Choung (1996), Storm-generated swaley bedding on the outer Scotian Shelf, Geo Mar. Lett., 16, 85-94.

Arnott, R. W., and J. B. Southard (1990), Exploratory flow-duct experiments on combined-flow bed configurations, and some implications for interpreting storm-event stratification, J. Sediment. Petrol., 60, 211-219.

Ashley, G. M., et al. (1990), Classification of large-scale subaqueous bedforms: A new look at an old problem, J. Sediment. Petrol., 60(1), $160-172$.

Carey, D. A. (1987), Sedimentological effects and palaeoecological implications of the tube-building polychaete Lanice conchilega Pallas, Sedimentology, 34, 49-66.

De Falco, G., S. Ferrari, G. Cancemi, and M. Baroli (2000), Relation between sediment distribution and Posidonia oceanica seagrass, Geo Mar. Lett., 20, 50-57.

Field, M. E., C. H. Nelson, D. A. Cacchione, and D. E. Drake (1981), Sand waves on an epicontinental shelf: Northern Bering Sea, Mar. Geol., 42, $233-258$.

Gallagher, E. L. (2003), A note on megaripples in the surf zone: Evidence for their relation to steady flow dunes, Mar. Geol., 193, 171-176.

Grasmeijer, B., M. Kleinhans, T. Dolphin, and C. Vincent (2005), Measured and predicted suspended sand transport and the effect of bedforms on a sandy shoreface (abstract), paper presented at Coastal Dynamics 2005, Lab. d'Eng. Maritima, Barcelona.

Greenwood, B., and D. J. Sherman (1986), Hummocky cross-stratification in the surf zone: Flow parameters and bedding genesis, Sedimentology, $33,33-45$.

Hennings, I., B. Lurin, C. Vernemmen, and U. Vanhessche (2000), On the behaviour of tidal current directions due to the presence of submarine sand waves, Mar. Geol., 169, 57-68.

Hill, P. R., S. Meulé, and H. Longuépée (2003), Combined-flow processes and sedimentary structures on the shoreface of the wave-dominated Grande-Rivière-de-la-Baleine delta, J. Sediment. Res., 73(2), 217-226.

Houthuys, R., A. Trentesaux, and P. De Wolf (1994), Storm influences on a tidal sandbank's surface (Middelkerke Bank, southern North Sea), Mar. Geol., 121, 23-41.

Hulscher, S. J. M. H. (1996), Tidal-induced large-scale regular bed form patterns in a three-dimensional shallow water model, J. Geophys. Res. $101,20,727-20,744$

Hulscher, S. J. M. H., and G. M. van den Brink (2001), Comparison between predicted and observed sand waves and sand banks in the North Sea, J. Geophys. Res., 106, 9327-9338.

Idier, D., and D. Astruc (2004), Mechanisms of megaripple generation: From dunes to megaripples (abstract), paper presented at Meeting on Marine Sand Wave and River Dune Dynamics (MARID), Univ. of Twente, Enschede, Netherlands, 1-2 April

Langhorne, D. N. (1982), A study of the dynamics of a marine sandwave, Sedimentology, 29(4), 571-594.

Li, M. Z., and C. L. Amos (1999a), Field observations of bedforms and sediment transport thresholds of fine sand under combined wave and currents, Mar. Geol., 158, 147-160.
Li, M. Z., and C. L. Amos (1999b), Sheet flow and large wave ripples under combined waves and currents: Field observations, model predictions and effects on boundary layer dynamics, Cont. Shelf Res., 19, $637-663$

Mitgaard, H. H. (1996), Inner shelf to lower shoreface hummocky sandstone bodies with evidence for geostrophic influenced combined flow, lower Cretaceous, west Greenland, J. Sediment. Res., 66(2), $343-353$

Myrow, P. M., and J. B. Southard (1991), Combined-flow model for vertical stratification sequences in shallow marine storm-deposited beds, J. Sediment. Petrol., 61, 202-210.

Németh, A. A., S. J. M. H. Hulscher, and H. J. de Vriend (2002), Modelling sand wave migration in shallow shelf seas, Cont. Shelf Res., 22, $2795-$ 2806.

Passchier, S. (2004), Distribution, geometry and orientation of megascale bedforms on the inner shelf, coast of Holland, $52-52^{\circ} \mathrm{N}$, based on echosounder data and side-scan sonar (abstract), paper presented at Meeting on Marine Sand Wave and River Dune Dynamics (MARID), Univ. of Twente, Enschede, Netherlands, 1-2 April.

Southard, J. B., and A. Boguchwal (1990), Bed configurations in steady unidirectional water flows. Part 2. Synthesis of flume data, J. Sediment. Petrol. 60, 658-679.

Southard, J. B., J. M. Lambié, D. C. Federico, H. T. Pile, and C. R. Weidman (1990), Experiments on bed configurations in fine sands under bidirectional purely oscillatory flow, and the origin of hummocky cross-stratification, J. Sediment. Petrol., 60, 1-17.

Swift, D. J. P., Jr., A. G. Figuerido, G. L. Freeland, and G. F. Oertel (1983), Hummocky cross-stratification and megaripples: A geological double standard, J. Sediment. Petrol., 53, 1295-1317.

Terwindt, J. H. J. (1971), Sand waves in the Southern Bight of the North Sea, Mar. Geol., 10, 51-67.

U.S. Army Corps of Engineers (1953), The united soil classification system, Tech. Memo. 3-357, U.S. Army Corps of Eng. Waterw. Exp. Stn., Washington, D. C.

Van Alphen, J. S. L. J., and M. A. Damoiseaux (1989), A morphological map of the Dutch shoreface and adjacent part of the continental shelf, Geol. Mijnbouw, 68, 433-443.

Van de Meene, J. W. H. (1994), The shoreface-connected ridges along the central Dutch coast, Ph.D. thesis, 222 pp., Neth. Geogr. Stud., Dep. of Geogr. Sci., Utrecht Univ., Utrecht, Netherlands.

Van de Meene, J. W. H., and L. C. van Rijn (2000), The shorefaceconnected ridges along the central Dutch coast-Part 1: Field observations, Cont. Shelf Res., 20, 2295-2323.

Van de Meene, J. W. H., J. R. Boersma, and J. H. J. Terwindt (1996), Sedimentary structures of combined flow deposits from the shorefaceconnected ridges along the central Dutch coast, Mar. Geol., 131, 151175

Van Dijk, T. A. G. P., and M. G. Kleinhans (2004), Processes controlling the behaviour of sand waves and megaripples in the North Sea (abstract), paper presented at Meeting on Marine Sand Wave and River Dune Dynamics (MARID), Univ. of Twente, Enschede, Netherlands, 1-2 April.

Wever, T. F. (2004), Bedforms and bedform migration, paper presented at Meeting on Marine Sand Wave and River Dune Dynamics (MARID), Univ. of Twente, Enschede, Netherlands, 1-2 April.

M. G. Kleinhans, Faculty of Geosciences, IMAU, P.O. Box 80115, 3508 TC Utrecht, Netherlands.

S. Passchier, Department of Earth and Environmental Studies, Montclair State University, Mallory Hall 252, Montclair, NJ 07043, USA. (passchiers@mail.montclair.edu) 